\title{
Alterations in the post-translational modification and intracellular trafficking of clusterin in MCF-7 cells during apoptosis
}

\author{
J O'Sullivan ${ }^{1,2,4}$, L Whyte ${ }^{1}$, J Drake ${ }^{3}$ and M Tenniswood ${ }^{\star, 1}$ \\ 1 Department of Biological Sciences, University of Notre Dame, Notre Dame IN \\ 46556, USA \\ 2 Graduate Program in Cell and Molecular Biology, University College Dublin, \\ Belfield, Ireland \\ 3 Center for Immunology and Microbial Disease, Albany Medical College, \\ Albany, NY 12208-3479, USA \\ * Corresponding author: M Tenniswood, Department of Biological Sciences, \\ University of Notre Dame, Notre Dame, IN 46556, USA. Tel: 574-631-3372; \\ Fax: 574-631-7413; E-mail: tenniswood.1@nd.edu \\ ${ }^{4}$ Current address: Department of Pathology, University of Washington, Seattle, \\ WA 98195, USA
}

Received 27.8.02; revised 15.1.03; accepted 13.3.03

Edited by E Salvesen

\begin{abstract}
Clusterin is a heterodimeric, disulfide-linked $70-80 \mathrm{kDa}$ glycoprotein that is induced during regression of most, if not all, hormone-dependent epithelial tissues. These studies describe the biogenesis and intracellular trafficking of clusterin in MCF-7 cells before and after the initiation of apoptosis with antiestrogens and TNF $\alpha$. Under physiological conditions, clusterin is modified in the endoplasmic reticulum (ER), and proteolytically cleaved in the Golgi to generate discrete $\alpha$ and $\beta$ chains prior to secretion. Treatment with TNF $\alpha$ or the antiestrogen, ICI 182,780 , induces apoptosis in MCF-7 cells and leads to substantial changes in the activity of Golgi-resident enzymes, significantly altering the biogenesis of clusterin. This leads to the appearance of a $50-53 \mathrm{kDa}$ uncleaved, nonglycosylated, disulfide-linked isoform of clusterin that accumulates in the nucleus. While clusterin contains a cryptic SV-40-like nuclear localization signal, mutation of this sequence does not affect the nuclear accumulation of the disulfide-linked nuclear isoform. Confocal microscopy demonstrates that the nuclear accumulation of clusterin is coincident with DNA fragmentation. These data suggest that, at least in secretory epithelial cells, retrograde transport from the Golgi to the ER of a nonglycosylated, uncleaved isoform and the subsequent translocation of clusterin to the nucleus occur in dying cells.

Cell Death and Differentiation (2003) 10, 914-927. doi:10.1038/ sj.cdd. 4401254
\end{abstract}

Keywords: clusterin; antiestrogens; glycoprotein; biogenesis; cell death
Abbreviations: ER, endoplasmic reticulum; BFA, Brefeldin A; FFE, free flow electrophoresis; Gal T, galactosyl transferase; Mann II, mannosidase II; NLS, nuclear localization signal; OST, oligosaccharide transferase.

\section{Introduction}

Epithelial cell death has been characterized in the secretory epithelium of the regressing breast after the ablation of the appropriate trophic hormones or administration of antiestrogens, ${ }^{1}$ and in the prostate after castration or administration of antiandrogens. ${ }^{2,3}$ One of the most prominent proteins induced during the regression of the rat ventral prostate or mammary gland is clusterin. ${ }^{1,4-8}$ Clusterin is encoded by a single copy gene located on chromosome 8 , just distal to the transition between $8 p 12$ and $8 p 21,{ }^{9,10}$ and chromosome 14 in the mouse. ${ }^{11,12}$ The gene has been isolated and sequenced from a number of species including human, ${ }^{10}$ rat $^{6}$ and mouse, ${ }^{12}$ and has a similar structure of nine exons and eight introns, spanning approximately $14 \mathrm{~kb}$ in the rat and $17 \mathrm{~kb}$ in the human. Primer extension analysis has shown that there is a single functional promoter in the rat and human genes. 6,10 Transcription of the clusterin gene gives rise to a single mRNA, $1.6 \mathrm{~kb}$ in length, which is translated on membranebound ribosomes ${ }^{13}$ and, like other proteins containing a hydrophobic leader sequence, is cotranslationally translocated to the lumen of the endoplasmic reticulum (ER) coincident with the cleavage of the signal peptide. Subsequent glycosylation in the (ER) and Golgi, and proteolytic cleavage of the protein between R205 and S206 produce a mature protein of 427 amino acids that is a secreted, disulfidebonded, heterodimeric glycoprotein containing different but similarly sized $\alpha$ and $\beta$ chains. ${ }^{14}$ (The numbering of the amino acids, and the position of the cleavages sites are based on the mature protein.) In the human, there are six $\mathrm{N}$-linked glycosylation sites, three on the $\alpha$ chain $(\alpha 64 \mathrm{~N}, \alpha 81 \mathrm{~N}$ and $\alpha 123 N)$ and three on the $\beta$ chain ( $\beta 64 N, \beta 127 \mathrm{~N}$ and $\beta 147 \mathrm{~N})$, all of which appear to be utilized. ${ }^{14,15}$ Clusterin also contains a cryptic SV-40-like nuclear localization signal (NLS) (SNLEEAKKKK), located between amino acids 50 and 60 of the mature protein. However, under normal homeostatic conditions, this localization sequence is not utilized since clusterin is translated on bound ribosomes and the protein is secreted.

Clusterin was first associated with cell death in the regressing rat ventral prostate, but has since been identified as an induced gene in numerous in vivo and in vitro models of epithelial cell death including the endometrium, ${ }^{16}$ kidney, ${ }^{17,18}$ pancreas, ${ }^{19}$ brain $^{20-22}$ and retinal tissue. ${ }^{23}$ While clusterin expression is clearly induced very significantly during cell death in these systems, it is also clear that clusterin is 
expressed constitutively in many adult organs in physiological circumstances that are not associated with apoptosis, most prominently in the testes, ${ }^{24,25}$ and complement system. ${ }^{26}$ In general, expression is spatially restricted to the epithelial compartment, ${ }^{3,27,28}$ and is found at significant levels in many extracellular fluids including blood, ${ }^{29}$ cerebral spinal fluid, ${ }^{30}$ and seminal fluid. ${ }^{31}$ However, in some cell types with a regulated exocytic pathway, including platelets, ${ }^{22,32}$ and in endocrine and neuroendocrine secretory tissues ${ }^{33,34}$ clusterin is stored in secretory granules and released upon stimulated exocytosis. In these contexts, it has been suggested that clusterin may play a role in cell survival.

Few studies have directly examined the effects of experimentally manipulating levels of clusterin expression on cell death and survival. In human prostatic LNCaP cells, overexpression of clusterin provides protection against TNF $\alpha$ induced cell death and oligonucleotide directed antisense inhibition enhances spontaneous cell death in untreated cultures. ${ }^{35}$ In L929 cells, overexpression of clusterin protects the cells against TNF $\alpha$-induced cell death. ${ }^{36}$ These data suggest that rather than being part of the cell death mechanism, as most of the in vivo data suggest, clusterin may have a cytoprotective role in epithelial cell death. Thus, it is unclear whether clusterin is directly involved in the apoptotic process, whether its induction is secondary to apoptosis, or whether the protein is induced as a protective or survival mechanism for the cell.

To address the issues relating to the functional role of clusterin in apoptosis we have used a monoclonal antibody raised against rat recombinant clusterin that recognizes both the wild-type clusterin and a unique "apoptosis-related" isoform of the protein. ${ }^{37}$ We have characterized the biogenesis of clusterin in MCF-7 cells by free flow electrophoresis (FFE), Western analysis and immunohistochemistry, both before and after treatment with TNF $\alpha$ or the pure antiestrogen $\mathrm{ICl} 182,780 .{ }^{38}$ Both of these compounds induce apoptotic cell death in MCF-7 cells in a dose- and time-dependent manner. $\mathrm{TNF} \alpha$ utilizes the extrinsic cell death pathway, while $\mathrm{ICI}$ 182,780 disrupts estrogen receptor-mediated signaling required for cell survival. The data demonstrate that there are significant alterations in the biogenesis of clusterin during apoptosis, which lead to the appearance of a nonglycosylated, disulfide-linked isoform in the nucleus of those cells which initiate DNA fragmentation.

\section{Results}

\section{Inhibition of cell proliferation and induction of apoptosis in MCF-7 cells}

The effects of TNF $\alpha, I C I 182,780$ and Brefeldin A (BFA) on the growth kinetics of MCF-7 cells in vitro are shown in Figure 1. All the three drugs induce growth inhibition and apoptosis in a time dependent manner. The induction of apoptosis was monitored by changes in cellular morphology, TUNEL analysis and DNA fragmentation (data not shown). The induction of apoptosis by ICI 182,780 is time- and dosedependent. Doses of $10 \mu \mathrm{M} \mathrm{ICl} 182,780$ induce growth arrest and apoptosis that is first visible at $24 \mathrm{~h}$, but is much more prominent at $96 \mathrm{~h}$ (Figure 1, panels $\mathrm{a}$ and b). MCF-7 cells are also sensitive to TNF $\alpha$ doses as low as $1 \mathrm{ng} / \mathrm{ml}$. When treated with this concentration of TNF $\alpha$, MCF-7 cells display $40-50 \%$ reduction in cell number as early as $24 \mathrm{~h}$, and this percentage increases to $85-90 \%$ by $72 \mathrm{~h}$ of incubation (Figure 1, panels $\mathrm{c}$ and $\mathrm{d}$ ). There is clear evidence of DNA fragmentation, as measured by TUNEL staining as early as $24 \mathrm{~h}$ after TNF $\alpha$ treatment (results not shown). In marked contrast, to both $\mathrm{TNF} \alpha$ and $\mathrm{ICl}$ 182,780, the fungal antibiotic, BFA, which induces rapid regression of the Golgi stack into rudimentary Golgi clusters in parallel with a redistribution of the Golgiresident proteins into the rough $\mathrm{ER}$, at doses of $5 \mu \mathrm{g} / \mathrm{ml}$ induce $70-80 \%$ of the cells to undergo cell death by $6 \mathrm{~h}$ (Figure 1, Panel e), although there is very little evidence of DNA fragmentation at this time in cells treated with BFA (results not shown).

\section{FFE analysis of clusterin biogenesis}

For FFE experiments, MCF-7 cells were treated with $1 \mathrm{ng} / \mathrm{ml}$ $\mathrm{TNF} \alpha$, or $10 \mu \mathrm{M} \mathrm{ICl} 182,780$, and harvested $24 \mathrm{~h}$ later, at which time the majority of the cells are in the early stages of apoptosis, prior to the formation of apoptotic bodies. The cells were harvested $6 \mathrm{~h}$ after BFA treatment. In untreated MCF-7 cells, marker enzyme analysis of purified subfractions from FFE indicates that organelles emerge mostly as single asymmetrical peaks, separated into different subfractions based on membrane surface charge and size (Figure 2, panel a). Based on marker enzyme profiles, the plasma membrane fraction is restricted to fractions $40-43$, lysosomal membranes are found in fractions 30-33, the Golgi apparatus is concentrated in fractions 35-39 and the ER is restricted to fractions 40-43. To determine the subcellular location associated with the post-translational modification of clusterin, the FFE fractions were concentrated, immunoblotted and probed with $6 \mathrm{E} 9$, the anticlusterin monoclonal antibody that recognizes both the wild-type clusterin and the putative apoptotic glyco/isoform of clusterin. ${ }^{37}$ In untreated MCF-7 cells, a $50-53 \mathrm{kDa}$ isoform of clusterin is present in the ER/ plasma membrane fraction (Figure 2, panel b). Since clusterin is known to be a secreted protein and is not localized on the membrane by immunohistochemistry, this isoform of clusterin most likely represents an isoform localized to the ER. In the Golgi fraction, the $\beta$-chain-specific monoclonal, 6E9, detects a $29 \mathrm{kDa}$ clusterin polypeptide, the product of the endopeptidase cleavage of clusterin into $\alpha$ and $\beta$ chains. There is no evidence of clusterin in the lysosomal fraction, and clusterin is secreted into the medium where it is detectable by Western analysis (data not shown). After treatment with $1 \mathrm{ng} / \mathrm{ml} \mathrm{TNF} \alpha$, there are significant, reproducible changes in the marker enzyme profiles and in the biogenesis of clusterin (Figure 3, panel a). While marker enzyme profiles for the ER, lysosomes and plasma membrane remain essentially unaltered, mannosidase II (mann II) activity is not detectable in the FFE fractions. However, after concentrating fractions 35-39 from FFE runs, and probing with the 6E9 monoclonal anticlusterin antibody, a $50-53 \mathrm{kDa}$ isoform clusterin is clearly detected in these fractions and in the fractions containing the Golgi apparatus (Figure 3, panel b). These data suggest that the internal proteolytic cleavage of clusterin in the Golgi apparatus is blocked after treatment with TNF $\alpha$. Similar changes in the 

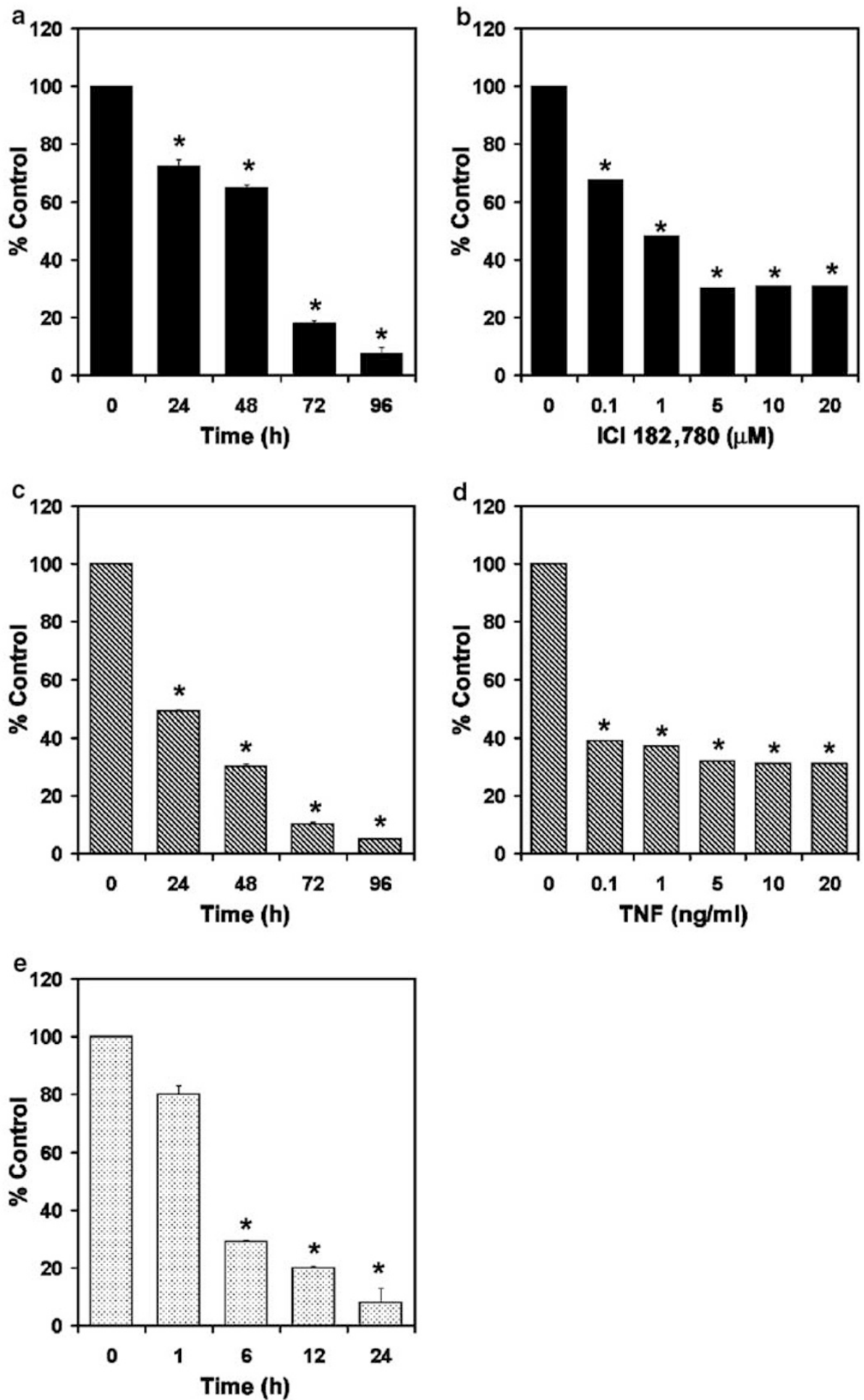

Figure 1 Growth kinetics of MCF-7 cells after treatment with TNF $\alpha$, ICl 182,780 or BFA. Time course (a, c, e) and dose response (b, d) of MCF-7 cells to ICl 182,780 $(\mathbf{a}, \mathbf{b}), \operatorname{TNF} \alpha(\mathbf{c}, \mathbf{d})$ or BFA $(\mathbf{e})$. (a, c, e) $2 \times 10^{4} \mathrm{MCF}-7$ cells, plated in 24 -well plates were treated in phenol red-free $\alpha$-MEM supplemented with $5 \% \mathrm{CSS}$ and $10 \mathrm{nM} 17 \beta$ estradiol with $10 \mu \mathrm{M} \mathrm{ICl} 182,780,1 \mathrm{ng} / \mathrm{ml} \mathrm{TNF} \alpha$ or $5 \mu \mathrm{g} / \mathrm{ml} \mathrm{BFA}$, respectively, for the indicated times. Cell numbers were assayed using crystal violet as described in Materials and Methods. (b, d) $2 \times 10^{4}$ MCF-7 cells, plated in 24-well plates were treated in phenol red-free $\alpha$-MEM supplemented with $5 \%$ CSS with increasing doses of $\mathrm{ICl} 182,780$ or TNF $\alpha$ for $72 \mathrm{~h}$. Untreated MCF-7 cells served as the control at each time point. Results are expressed as mean + S.D. of three independent experiments. ${ }^{*} P<0.05$. 

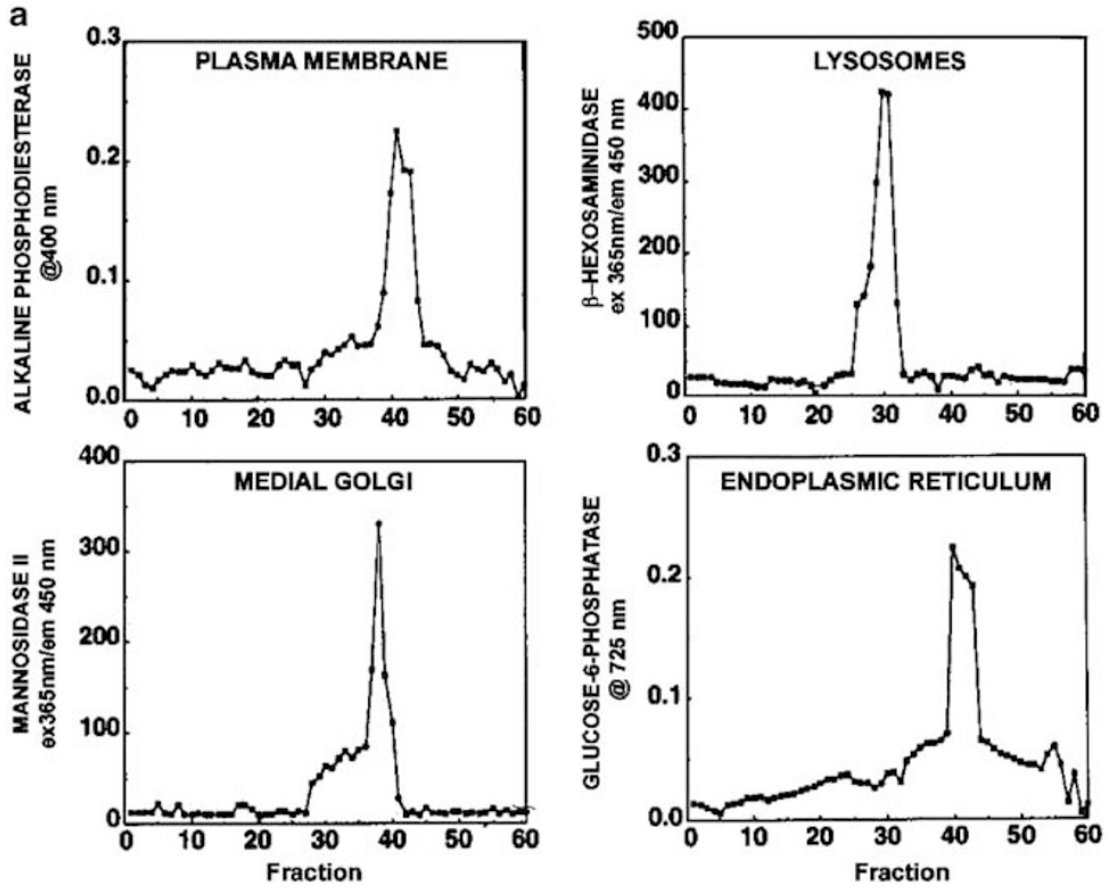

b

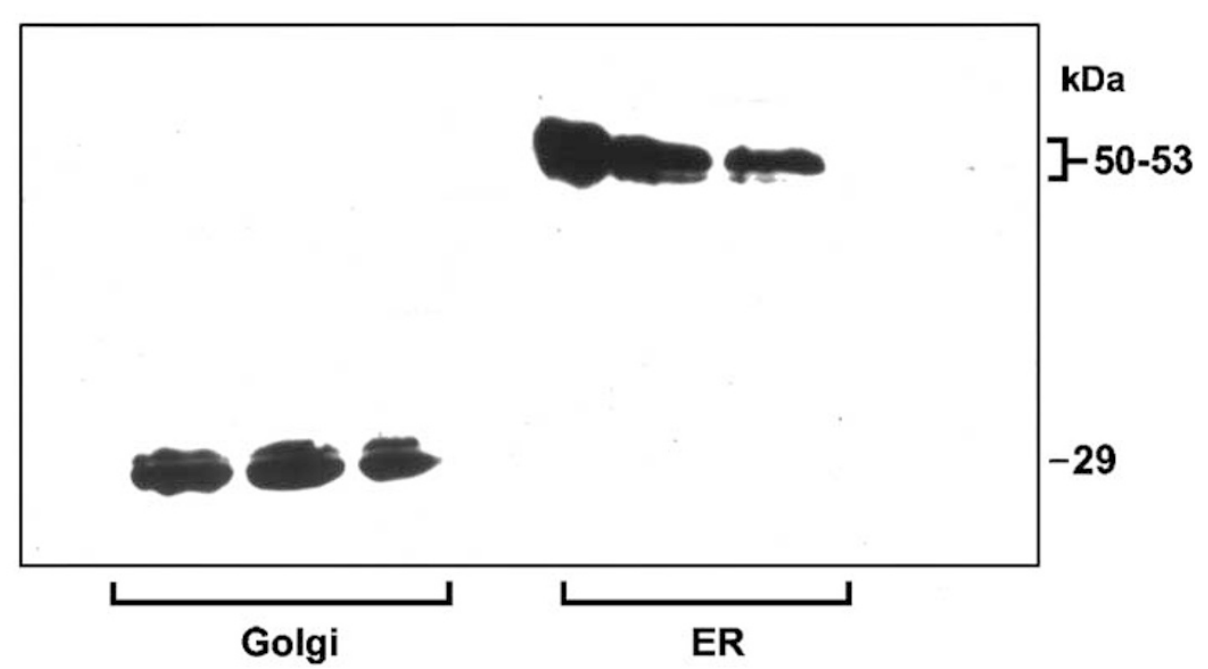

Figure 2 Analysis of intracellular processing of clusterin in untreated MCF-7 cells using FFE. (a) Marker enzyme profiles for untreated MCF-7 cells. FFE fractions were collected and assayed for marker enzyme activities as described in Materials and Methods. (b) Intracellular processing of clusterin. FFE fractions were collected, concentrated and electrophoresed on reducing 12.5\% SDS-PAGE. The proteins were transferred to nitrocellulose membranes, probed with 6 E 9 , the anticlusterin antibody as described in Materials and Methods. The ER (fractions 41, 42 and 43) contains a 50-53 kDa intermediate precursor, which is proteolytically cleaved in the Golgi apparatus (fractions 36,37 and 38 ) to produce the $29 \mathrm{kDa} \beta$ chain that is detected by $6 \mathrm{E} 9$.

biogenesis of clusterin are seen when the cells are treated with $10 \mu \mathrm{M} \mathrm{ICI} 182,780$ (Figure 3, panel c), although the loss of mann II enzymatic activity is not as pronounced after treatment with the pure antiestrogen (data not shown). The secretion of clusterin is also reduced, but not eliminated, after treatment with both these apoptotic inducers (data not shown). These changes in clusterin biogenesis demonstrate that the proteolytic cleavage required to produce the mature secretory form of the protein does not occur in the Golgi after treatment with either $\mathrm{TNF} \alpha$ or ICI 182,780.
When treated with $5 \mu \mathrm{g} / \mathrm{ml}$ BFA, clusterin secretion from MCF-7 cells is inhibited in a time-dependent manner (data not shown). Furthermore, FFE and Western analysis demonstrate that clusterin is inefficiently transported to the Golgi, and is not processed by proteolysis (Figure 3, Panel d). Thus, while BFA clearly exerts a very significant effect on the proteolytic conversion of clusterin to the mature $\alpha$ and $\beta$ chains, it does so primarily by blocking the anterograde transport of clusterin from the endoplasmic reticulum (ER) to the Golgi, where terminal glycosylation of oligosaccharide 
chains in glycoproteins and proteolytic processing of clusterin takes place. Thus, although treatment with $\mathrm{TNF} \alpha$ and $\mathrm{ICl}$ 182,780 also results in the failure to cleave clusterin proteolytically, the effect appears to be directly related to the
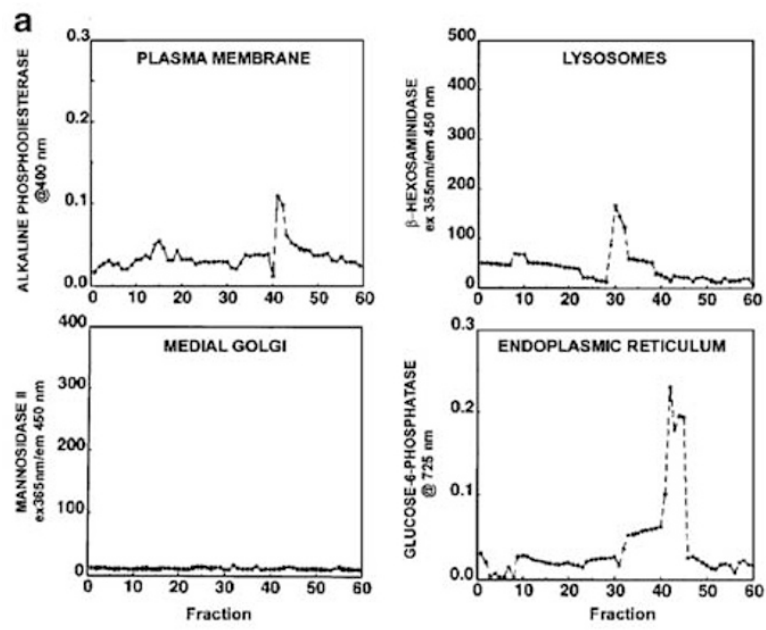

b
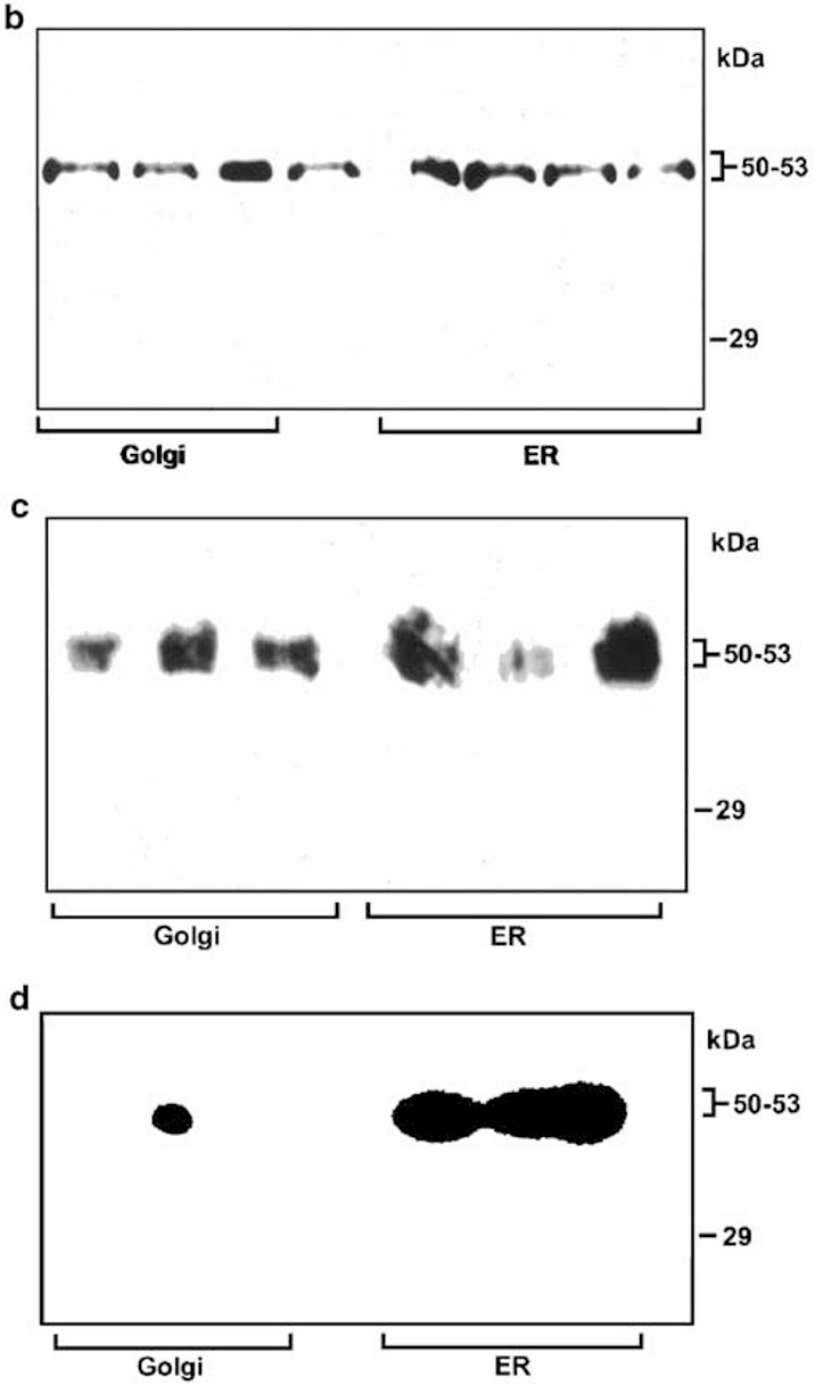

proteolytic processing itself, since clusterin is translocated to the Golgi.

\section{Expression of mann II and galactosyl transferase (Gal T) in MCF-7 cells after treatment with TNF $\alpha$ or ICI 182,780}

Mannll is a $124-130 \mathrm{kDa}$ glycoprotein that is normally resident in the cis/medial Golgi. It is synthesized as a glycoprotein and is modified during transit through the ER to the Golgi. This modification varies slightly from cell type to cell type resulting in variation in the size of glycoprotein. ${ }^{39}$ To determine whether the loss of mann II enzymatic activity seen in the purified FFE fractions is reflective of generalized changes in the expression of Golgi proteins or because of the fractionation procedure, we examined the expression of this enzyme in cytosolic extracts of MCF-7 cells after treatment with TNF $\alpha$ or ICI 182,780. The level of mann II cytosolic protein decreases rapidly after treatment with $1 \mathrm{ng} / \mathrm{ml}$ TNF $\alpha$ (Figure 4 , panel a), and mann II is barely detectable in MCF-7 cells 48 h after treatment with TNF $\alpha$. Immunofluorescent studies using the same antibody, confirm the dramatic decrease in the expresssion of mann II $48 \mathrm{~h}$ after treatment (Figure 4, panel a). The expression of mann II in untreated MCF-7 cells is diffuse, while after treatment with TNF $\alpha$, the structure of the Golgi apparatus appears to alter, as indicated by the different staining pattern of mann II surrounding the nucleus (Figure 4, panel b). In particular, the level of mann II staining in the Golgi varies noticeably among cells observed at the same time after treatment, suggesting that the Golgi apparatus undergoes a progressive inactivation and/or disruption after TNF $\alpha$ treatment. A similar reduction in the level of mann II expression is detected after treatment with $10 \mu \mathrm{M} \mathrm{ICl} 182,780$, both by Western analysis and by immunofluorescence (Figure 4, panel b). However, the time frame of the changes in mann II expression is considerably more extended than seen with $\mathrm{TNF} \alpha$ and the morphological disruption is not as dramatic. No reduction in the expression levels of mann II is detected after BFA treatment (data not shown).

The changes in mann II activity after treatment with TNF $\alpha$ and $\mathrm{ICI} 182,780$ are reflected in the processing of galactosyl transferase (Gal T). Prior to treatment, MCF-7 cells express the mature $45 \mathrm{kDa}$ form of Gal T (Figure 4, panel c). At $48 \mathrm{~h}$ after TNF $\alpha$ treatment, there is a significant decrease in the

Figure 3 Intracellular processing of clusterin after TNF $\alpha$ or ICl182,780 or BFA treatments. (a) Marker enzyme profiles for MCF-7 cells treated with TNF $\alpha$ (1 ng/ $\mathrm{ml}$ ) for $24 \mathrm{~h}$ using FFE. FFE fractions were collected and assayed for marker enzyme activities as described in Materials and Methods. (b) Intracellular processing of clusterin in the ER and the Golgi apparatus after treatment with $1 \mathrm{ng} / \mathrm{ml} \mathrm{TNF} \alpha$ for $24 \mathrm{~h}$. FFE fractions were collected, concentrated and electrophoresed on $12.5 \%$ SDS PAGE, samples containing $2.5 \% \beta$-mercaptoethanol. The proteins were transferred to nitrocellulose membranes, probed with $6 \mathrm{E} 9$ as described in Materials and Methods. Clusterin is present in the ER and Golgi as a $50-53 \mathrm{kDa}$ intermediate precursor, indicating that internal proteolytic cleavage, to produce the $29 \mathrm{kDa} \beta$ chain, does not occur. (c) Intracellular processing of clusterin in the ER and the Golgi apparatus after treatment with $10 \mu \mathrm{M} \mathrm{ICl} 182,780$ for $24 \mathrm{~h}$. There is no evidence of proteolytic cleavage. (d) Intracellular processing of clusterin in the ER and the Golgi apparatus after treatment with $5 \mu \mathrm{g} / \mathrm{ml} \mathrm{BFA}$ for $6 \mathrm{~h}$. Clusterin is present in the ER as a $50-53 \mathrm{kDa}$ intermediate precursor; however little, if any, clusterin is found in the Golgi apparatus. 
a

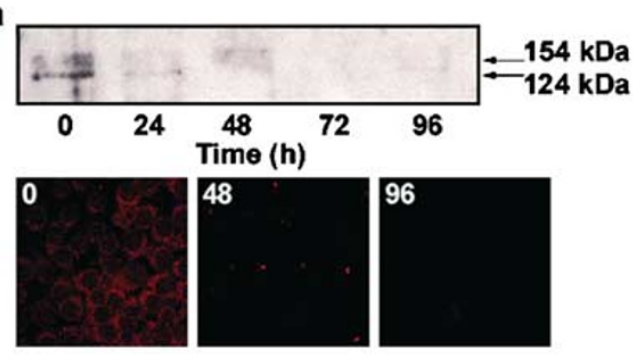

b

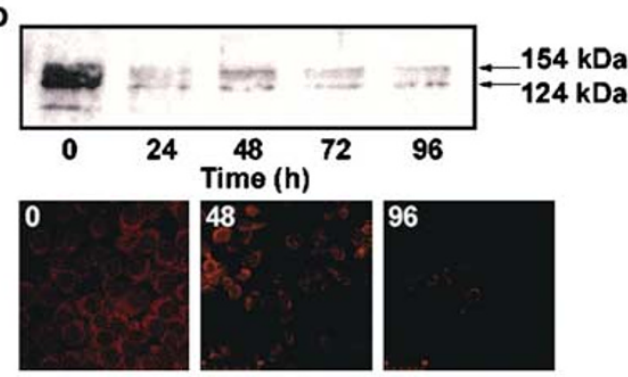

C

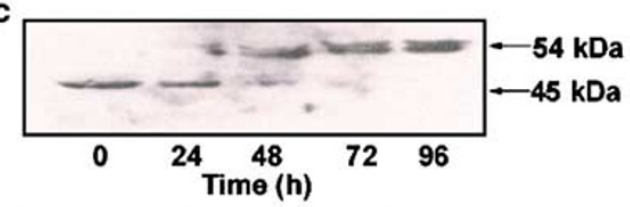

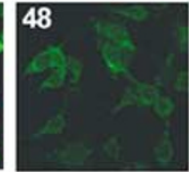

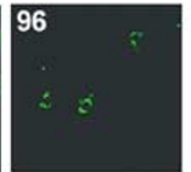

d

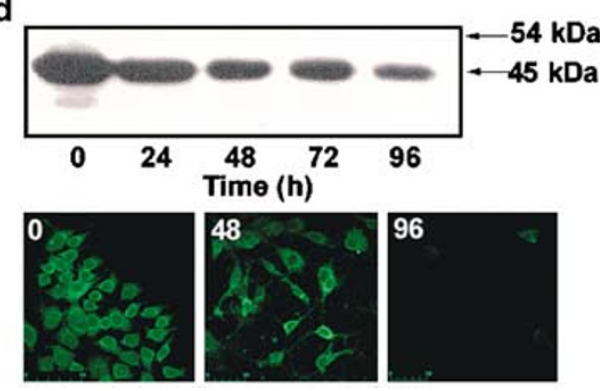

Figure 4 Expression of mann II and Gal T after treatment with $\mathrm{TNF} \alpha$ or $\mathrm{ICl}$ 182,780 treatments. (a) MCF-7 cells were treated for the indicated times with $1 \mathrm{ng} / \mathrm{ml} \mathrm{TNF} \alpha$ and processed for Western analysis (upper panel) or immunofluorescence (lower panel) using polyclonal antibody specific for mann II, as described in Materials and Methods. (b) MCF-7 cells were treated for the

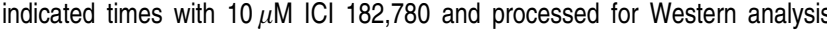
(upper panel) or immunofluorescence (lower panel) using a polyclonal antibody specific for mann II, as described in Materials and Methods. (c) MCF-7 cells were treated for the indicated times with $1 \mathrm{ng} / \mathrm{ml} \mathrm{TNF} \alpha$ and processed for Western analysis or immunofluorescence using a polyclonal antibody specific for Gal T, as described in Materials and Methods. (d) MCF-7 cells were treated for the indicated times with $10 \mu \mathrm{M} \mathrm{ICl} \mathrm{182,780} \mathrm{and} \mathrm{processed} \mathrm{for} \mathrm{Western} \mathrm{analysis} \mathrm{or}$ immunofluorescence using a polyclonal antibody specific for Gal T as described in Materials and Methods. This blot was exposed for longer times to confirm that the $54 \mathrm{kDa}$ band was not expressed.

level of the $45 \mathrm{kDa}$ form, and the appearance of a higher molecular weight $54 \mathrm{kDa}$ isoform. This isoform appears to accumulate as a result of the loss of mann II activity, and the concomitant failure to remove the terminal mannose residues from Gal T. After treatment of MCF-7 cells with ICl182,780, there is a steady decrease in the level of the mature isoform of Gal T; however, the higher molecular weight isoform is not detected even after extended exposure times (Figure 4, panel d), probably because of the continued presence of sufficient mann II in the medial Golgi (see Figure 4, panel b) to ensure appropriate post-translational cleavage of the terminal mannose residues in Gal T and other glycoproteins transiting the medial Golgi. This relation between the presence of mann II and the mature $45 \mathrm{kDa}$ isoform of $\mathrm{Gal} \mathrm{T}$ is further illustrated after treatment with BFA. At $6 \mathrm{~h}$ after treatment of MCF-7 cells with BFA, both the 54 and $45 \mathrm{kDa}$ isoforms are present in the cell, while at $12 \mathrm{~h}$ after treatment, only the mature $45 \mathrm{kDa}$ isoform is evident, presumably because of the continuing activity of mann II (results not shown).

\section{Translocation of clusterin to the nucleus in MCF-7 cells after treatment with TNF $\alpha$ and ICI 182,780.}

The changes in the processing of clusterin in the Golgi lead to a decrease in the secretion of the protein (data not shown); however, there is a concomitant accumulation of a $50-53 \mathrm{kDa}$ isoform in the nucleus 72-96 h after treatment of MCF-7 cells with either TNF $\alpha$ or ICI 182,780 (Figure 5, panels a and b). This isoform accumulates in the nucleus between 72 and $96 \mathrm{~h}$ after treatment with either TNF $\alpha$ or the antiestrogen. This is not because of ER contamination of the nuclear fractions, since there is no appreciable contamination of glucose-6phosphatase (the marker for the ER) in the nuclear preparations (Figure 5, panel $c$ and d). In contrast, there is no nuclear accumulation of clusterin after BFA treatment (data not shown). Since clusterin is secreted by both normal and dying cells, it is difficult to quantitate accurately the proportion of the protein that is redirected to the nucleus in dying cells. However, based on Western analysis of concentrated medium and nuclear extracts, it appears that between 5 and $15 \%$ of the total clusterin synthesized is localized to the nucleus of adherent cells.

The nuclear isoform of clusterin isolated from MCF-7 cells treated with either $1 \mathrm{ng} / \mathrm{ml} \mathrm{TNF} \alpha$ or $10 \mu \mathrm{M} \mathrm{ICl} 182,780$ does not appear to contain any $\mathrm{N}$-linked oligosaccharides since treatment with PNGase F does not alter the electrophoretic mobility of the protein (Figure 6, panel a). However, clusterin isolated from the nucleus after treatment with either TNF $\alpha$ or ICI 182,780 does appear to be disulfide-linked since the electrophoretic mobility is significantly altered by the addition of $\beta$-mercaptoethanol (Figure 6 , panels $\mathrm{b}$ and $\mathrm{c}$ ). The additional bands in the nonreduced lanes are most likely because of the presence of small amounts of reducing reagents in the initial homogenization buffer.

To determine whether the nuclear isoform of clusterin is expressed predominantly in surviving or dying cells, clusterin and TUNEL staining were performed on the same cells. Colocalization studies in MCF-7 cells using TUNEL staining and the 6E9 anticlusterin monoclonal antibody demonstrate that after treatment with TNF $\alpha$ or ICI 182,780 for $72 \mathrm{~h}$, nuclear clusterin is exclusively localized to cells that have initiated DNA fragmentation (Figure 7, Panel a). In cells treated with either $\mathrm{TNF} \alpha$ or ICI 182,780 , clusterin levels are upregulated 
a

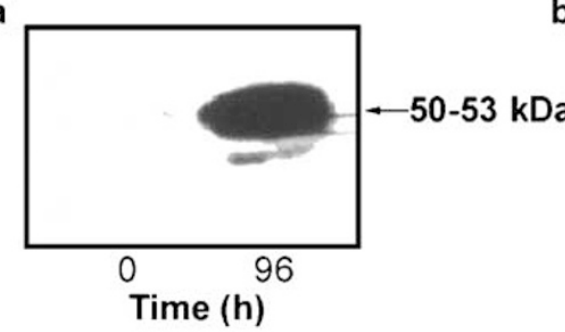

b

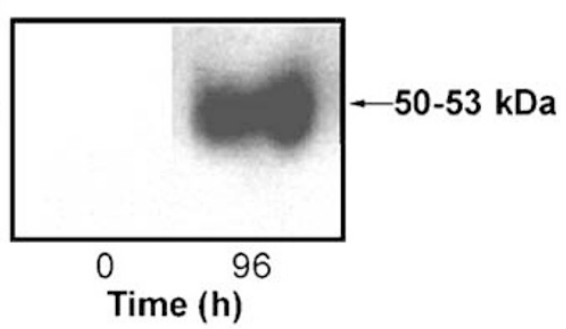

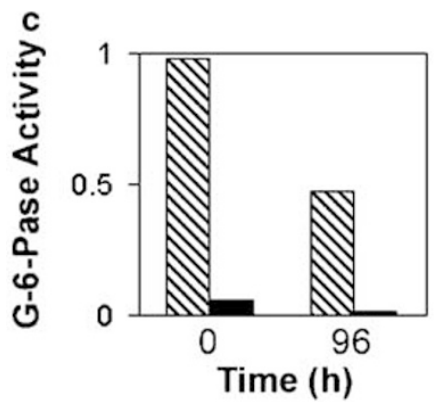

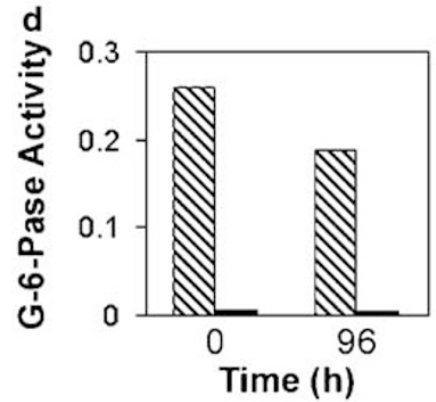

Figure 5 Characterization of the nuclear isoform of clusterin. MCF-7 cells were treated for $96 \mathrm{~h}$ with $1 \mathrm{ng} / \mathrm{ml} \mathrm{TNF} \alpha$ (panels $\mathbf{a}, \mathbf{c}$ ) or $10 \mu \mathrm{M} \mathrm{ICl} 182,780$ (b, d). (a and $\mathbf{b}$ ) Aliquots of the nuclear fractions were electrophoresed on 12.5\% SDS-PAGE gels, transferred to nitrocellulose membrane and probed with the anticlusterin monoclonal antibody 6E9. (c, d) Protein extracts from postnuclear supernatants (hatched bars) and nuclear pellets (solid bars) were prepared and assayed for glucose-6phosphatase (the ER marker enzyme) to monitor contamination of the nuclear fraction by the ER as described in Materials and Methods.

and the localization of the protein in the cytoplasm becomes punctate, suggesting that the protein is accumulating within the endomembrane system. Furthermore, a significant proportion of the protein is localized in the nuclei, which also demonstrates extensive DNA cleavage. While all cells expressing nuclear clusterin also show evidence of DNA fragmentation, between 20 and $30 \%$ of the TUNEL-positive nuclei cells do not contain clusterin, regardless of the drug or dosage used (Figure 7, Panels $b$ and $c$ ). This suggests that DNA fragmentation precedes the translocation of clusterin to the nucleus, and further that this translocation is not the trigger for DNA fragmentation.

\section{Role of cryptic NLS in nuclear accumulation of clusterin during apoptosis}

While these data provide strong evidence that a nonglycosylated isoform of clusterin accumulates in the nucleus of MCF-7 cells undergoing apoptosis after treatment with $\mathrm{TNF} \alpha$ or $\mathrm{ICl}$

Figure 6 Effect of TNF $\alpha$ or ICl 182,780 on glycosylation and disulfide bond formation of the nuclear isoform of clusterin. (a) Glycosylation state of the nuclear isoform of clusterin. MCF-7 cells were treated with $1 \mathrm{ng} / \mathrm{ml} \mathrm{TNF} \alpha$ or $10 \mu \mathrm{M} \mathrm{ICl}$ 182,780 for $96 \mathrm{~h}$ and processed for Western analysis. Purified nuclear samples were treated with or without $1000 \mathrm{U}$ PNGase F as described in Materials and Methods. No decrease in molecular weight was detected, indicating that the nuclear glyco/isoform of clusterin expressed during apoptosis is not glycosylated. (b, c) Disulfide bond formation in the nuclear isoform of clusterin. MCF-7 cells were treated for the indicated times with $1 \mathrm{ng} / \mathrm{ml} \mathrm{TNF} \alpha$ (b) or $10 \mu \mathrm{M} \mathrm{ICl} 182,780$ (c). Purified nuclear fractions were prepared as outlined in Materials and Methods. Aliquots of the nuclear fractions were electrophoresed on $12.5 \%$ nondenaturing PAGE gels, transferred to nitrocellulose membrane and probed with the anticlusterin monoclonal antibody $6 \mathrm{E} 9$. Each time point sample was run in the absence or presence of $2.5 \% \beta$-mercaptoethanol in the sample loading buffer.
182,780 , they do not provide any indication of the mechanism leading to this accumulation. As described earlier, clusterin contains a perfect SV40-type NLS between amino acids 50
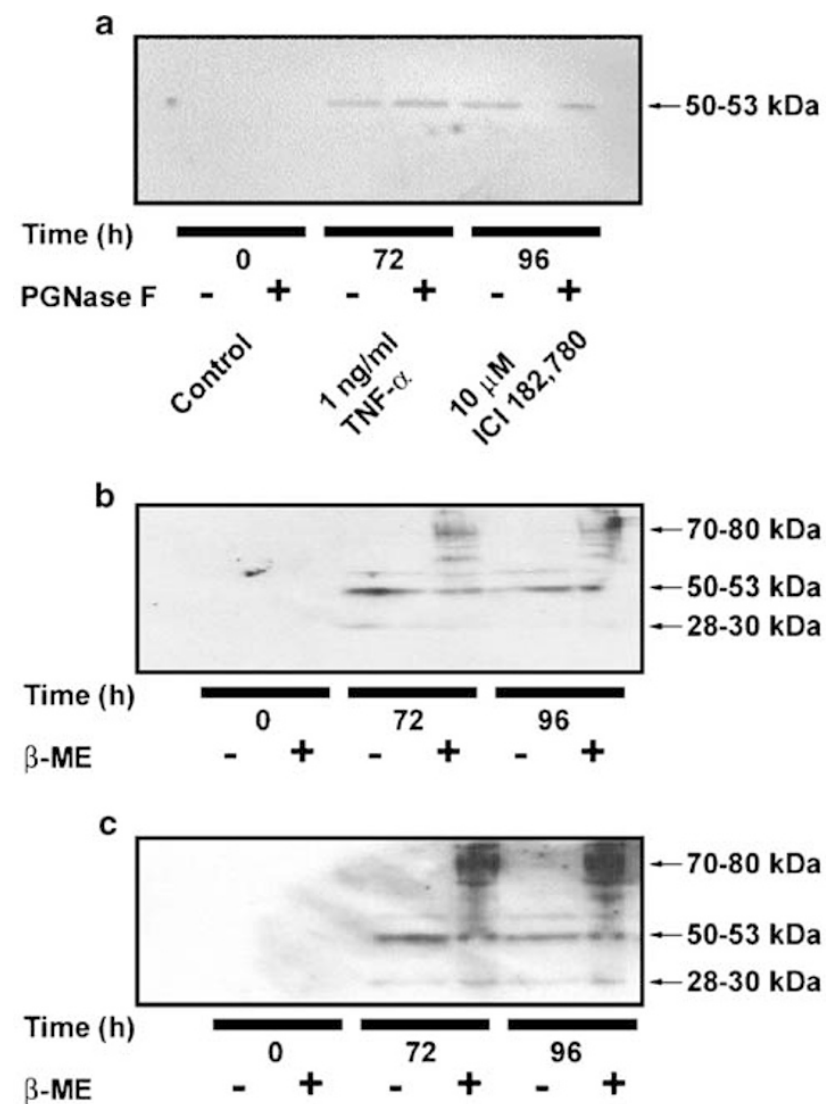


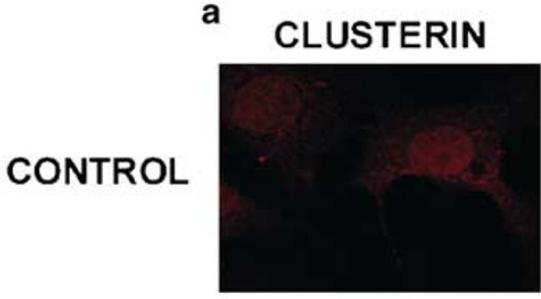

TNF- $\alpha$

(10ng/ml)

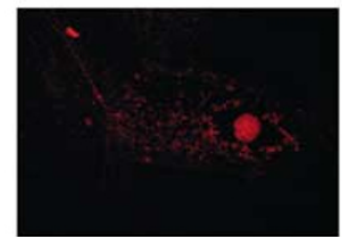

ICI 182,780

(10uM)
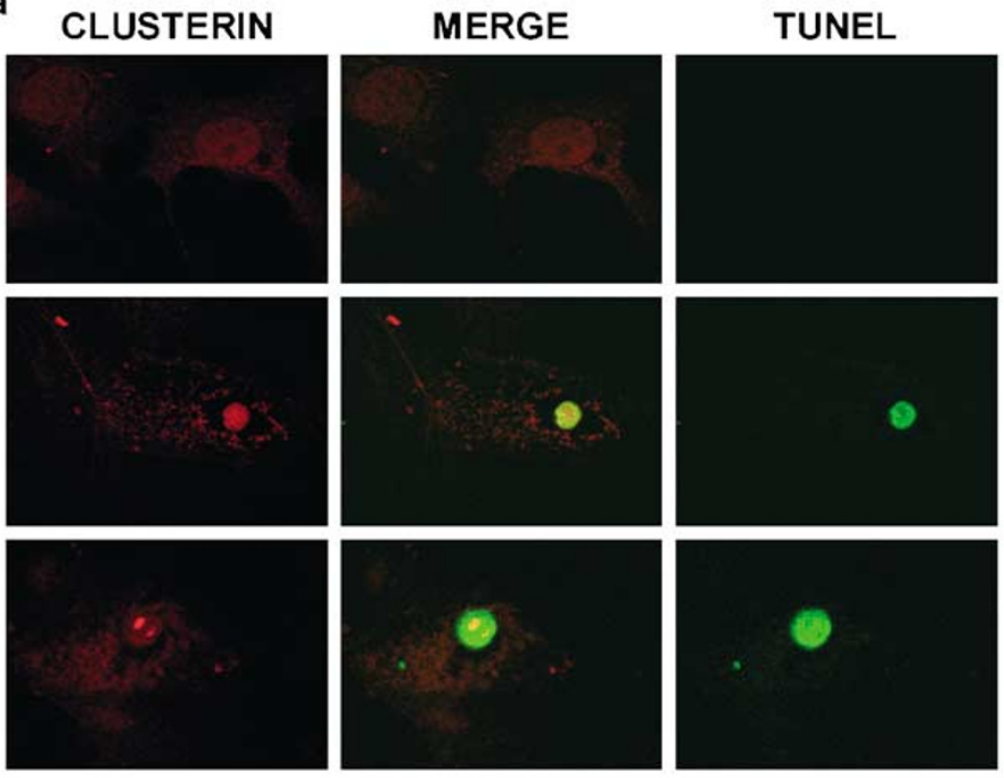

b

TNF- $\alpha$
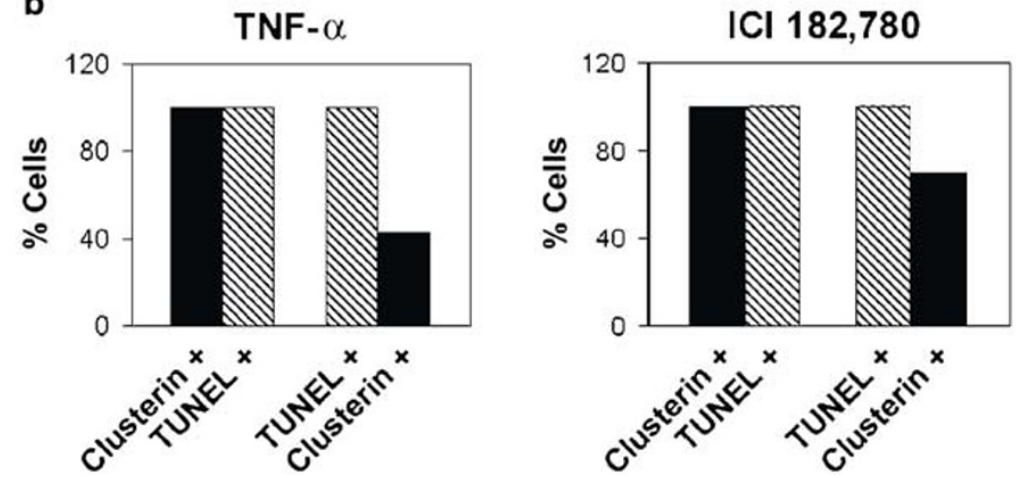

Figure 7 Localization of clusterin in the nuclei of apoptotic cells. (a) MCF-7 cells were treated with $1 \mathrm{ng} / \mathrm{ml}$ TNF $\alpha$ or $10 \mu \mathrm{M} \mathrm{ICl} 182,780$ for $96 \mathrm{~h}$, and fixed for TUNEL staining and immunofluorescence using the $6 \mathrm{E} 9$ anticlusterin monoclonal antibody and analyzed by confocal microscopy as described in Materials and Methods. Clusterin expression is visualized with 6E9 and Cy3-labeled secondary antibody. Fragmented DNA is visualized using TUNEL labeling with fluorescein-labeled nucleotides. Merged images were created using Confocal Assistant and Abode Photoshop. (b, c): Relation between clusterin-positive and TUNEL-positive cells in cells treated with $10 \mathrm{ng} / \mathrm{mI} \mathrm{TNF} \alpha(\mathbf{b})$ or $10 \mu \mathrm{M} \mathrm{ICl} \mathrm{182,780}$ (c). Nuclear clusterin-positive cells (solid bars) were assessed for DNA fragmentation by TUNEL staining (hatched bars). TUNEL-positive cells were also assessed for nuclear clusterin expression.

and 60 on the mature $\alpha$ chain. During normal synthesis and secretion, this NLS is not normally utilized since the protein is translated on membrane-bound ribosomes, and is translocated to the lumen of the ER, where it is folded and glycosylated, effectively sequestering it away from the nuclear transport machinery. To determine whether the NLS is required for the translocation of clusterin to the nucleus after treatment with TNF $\alpha$ or antiestrogens, the NLS was mutated and the effects of this mutation on the nuclear localization after induction of apoptosis were examined. To distinguish the mutated proteins from the endogenous clusterin, the mutant construct was cloned into the pcDNA6 vector in frame with the myc epitope (Figure 8, panel a). Using a mouse monoclonal antibody specific for the myc epitope to detect the mutated clusterin, it is clear that clusterin containing the mutated NLS is still efficiently translocated to the nucleus after treatment with $\mathrm{TNF} \alpha$ or $\mathrm{ICI} 182,780$ treatment, suggesting that the NLS is not utilized for the relocalization of the protein to the nucleus after treatment with $\mathrm{TNF} \alpha$ or $\mathrm{ICl} 182,780$ (Figure 8, panel b).

\section{Discussion}

Clusterin was originally identified as a sulfated glycoprotein synthesized by the Sertoli cells of the testes, and was proposed to play a significant role in sperm maturation. ${ }^{40,41}$ The same gene product was identified and cloned from the regressing rat ventral prostate and shown to be substantially induced in both the regressing prostate and mammary gland after hormone ablation or antihormone therapy. $3,4,8,42$ The expression of clusterin in these physiological contexts of tissue regression suggests that the protein may play a role in apoptotic cell death. However, the expression of the protein in numerous pathophysiological systems that do not involve apoptotic cell death has raised doubts as to whether the protein is involved in apoptosis and it has been suggested that 


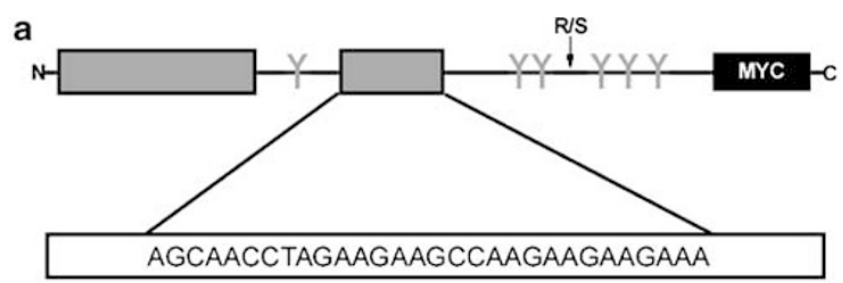

$S \quad N \quad L \quad E \quad E \quad A \quad K \quad K \quad K \quad K$

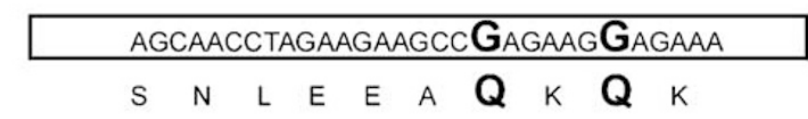

b

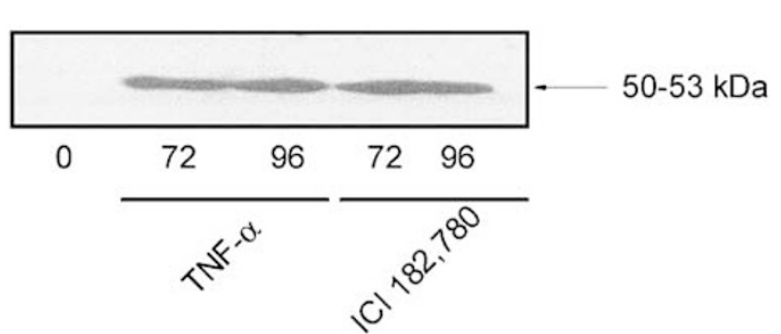

Figure 8 Nuclear localization of clusterin does not require the NLS. (a) Details of the point mutations in the NLS of clusterin. (b) MCF-7 cells, stably transfected with a clusterin construct containing the mutated NLS and containing a Cterminal myc epitope tag were treated with $10 \mathrm{ng} / \mathrm{ml} \mathrm{TNF} \alpha$ or $10 \mu \mathrm{M} \mathrm{ICl} 182,780$ for the indicated times. Purified nuclear samples were prepared as described in Materials and Methods and Western blotted using an antibody specific for the myc epitope.

the protein may even confer a survival advantage. ${ }^{28,43}$ This latter suggestion is further supported by the characterization of the secreted protein as an effective extracellular Type II chaperone that solubilizes partially denatured proteins..$^{44,45}$ There is considerable heterogeneity in the post-translational modification of clusterin, perhaps most dramatically illustrated by the testes-specific sulfation of the glycoprotein, ${ }^{42,46}$ suggesting that the function of the glycoprotein may be altered by its post-translational modification.

The data presented in this manuscript demonstrate that the biosynthesis and post-translational modification of clusterin are dramatically altered in MCF-7 cells after the induction of cell death by either TNF $\alpha$ or ICI 182,780. In untreated MCF-7 cells, clusterin is synthesized as $50-53 \mathrm{kDa}$ protein that is initially glycosylated in the ER, presumably by oligosaccharide transferase (OST) during cotranslational transport through the translocon. ${ }^{13}$ The nascent glycoprotein is modified by the ER-resident glucosidase and mannosidase I, folded with the assistance of calnexin and ERp57, and after disulfide bond formation the protein is transported to the Golgi apparatus. ${ }^{47}$ Further processing of the oligosaccharide chains in the Golgi by modifying enzymes including mann II and Gal T, and cleavage of the proprotein produces the mature $70-80 \mathrm{kDa}$ glycoprotein containing distinct disulfide-linked $\alpha$ and $\beta$ chains. ${ }^{48}$

The biosynthesis of clusterin is disrupted at several levels after the induction of apoptosis by TNF $\alpha$ or ICI 182,780. First, while the nascent protein is translocated from the ER to the Golgi, the protein is not modified by proteolysis to produce the $\alpha$ and $\beta$ chains. Secondly, after treatment of MCF-7 cells with either compound, clusterin accumulates in the ER and Golgi, and subsequently in the nucleus. The nuclear isoform is disulfide linked, indicating that the protein is still cotranslationally translocated to the ER after treatment. However, the protein is not glycosylated, implying that either the nascent protein is not initially glycosylated by OST, or that the glycoprotein is deglycosylated prior to retrograde transport to the ER and nucleus. While it is not possible to distinguish between these two processes based on the present data, the former process is more likely. The initial glycosylation events are mediated by OST during translocation into the lumen of the ER, which is only active if DAD-1 (defender against death) is associated with the OST complex. ${ }^{49-52}$ Thus, in the absence of DAD-1, clusterin (and other glycoproteins) will not be appropriately cotranslationally modified. In the absence of DAD-1, the protein will be translocated in the ER and the nonglycosylated protein will still be correctly folded (through interaction with calreticulin and Grp78), disulfide linked (by peptide disulfide isomerase) in the ER, and translocated to the Golgi. However, the nonglycosylated isoform of clusterin is not cleaved in the Golgi by the endopeptidase, suggesting that the proteolytic processing is restricted to the fully glycosylated isoform. The mechanism of DAD-1 inactivation is not well understood. There are no obvious phosphorylation or caspase cleavage sites in the protein that might provide an explanation for the inactivation of DAD-1 after the initiation of apoptosis via either the intrinsic or extrinsic cell death pathways. ${ }^{49}$ This raises the possibility that the activity of the OST complex may be mediated by transcriptional regulation of DAD-1 levels.

Since the uncleaved $50-53 \mathrm{kDa}$ isoform of clusterin is seen in the Golgi after the induction of apoptosis, the subsequent accumulation of clusterin in the ER appears to be because of the failure of the endopeptidase to cleave the protein, leading to the retrograde transport of the uncleaved, nonglycosylated protein from the Golgi back to the ER. This process is distinct from that induced by BFA, swainsonine or tunicamycin, since these drugs also block the anterograde transport of clusterin from the ER to the Golgi. ${ }^{53-55}$ In this respect, the changes in the glycosylation of clusterin are reflected in the changes in the synthesis and glycosylation pattern of mann II and Gal T, two proteins that are resident in the cis- and medial Golgi respectively. ${ }^{39,56}$ The levels and degree of glycosylation (as assessed by the changes in mobility on Western analysis) indicate that both $\mathrm{TNF} \alpha$ and $\mathrm{ICl} 182,780$ have relatively pleotropic effects on the glycosylation processes that are not only restricted to changes in the glycosylation of secreted proteins but also affects modifying enzymes resident in the Golgi and probably ER, implying that the glycosylation pattern of many, if not all, glycoproteins will be altered significantly.

The presence of clusterin in the nucleus has been noted previously under several other pathophysiological conditions, including human hepatoma HepG2 and mink lung epithelial CCL64 cells treated with TGF $\beta,{ }^{57}$ Shionogi mouse mammary carcinomas after repeated hormone ablation ${ }^{58}$ and in MCF-7 cells after irradiation. ${ }^{59}$ In these previous studies, the nature of the nuclear isoform was not determined, although it has been suggested that the initiation of translation from a second methionine present in the human clusterin sequence $\left(\alpha^{1} 2 \mathrm{M}\right)$ 
on free ribosomes would produce a protein lacking the signal sequence which should then be translocated to the nucleus. This is unlikely in our view since this particular amino-acid residue is not conserved in rodent species, and, as this present study documents, the isoform that accumulates in the nucleus is a disulfide-linked protein. Furthermore, this very unusual translocation to the nucleus of the disulfide-linked, nonglycosylated isoform of clusterin does not appear to require the NLS. Since mutation of the NLS does not alter the accumulation of nuclear clusterin, this suggests that the nuclear accumulation of clusterin does not require the interaction of the protein with the nuclear import system from the cytoplasm. This also suggests that the integrity of the Golgi/ER endomebrane complex is not compromised and that there is a mechanism that permits the translocation of the disulfide-linked clusterin across the inner nuclear membrane. It is interesting to note that the ER and inner nuclear membrane are contiguous, and although the mechanism does not appear to involve the formation of new pores, the process is selective since overload of the ER after BFA, swainsonine or tunicamycin does not induce nuclear accumulation of clusterin. These changes in clusterin biogenesis during apoptosis appear to be contemporaneous with ER overload, but precede the proteolytic degradation of the nuclear lamins that marks the initiation of nuclear fragmentation (O'Sullivan, unpublished observations), suggesting that the translocation is not a very late event that only occurs after the integrity of the nuclear membrane has been lost. It is also possible, but unlikely in our view, that the accumulation of nonglycosylated, disulfide-linked isoform in the nucleus is a by-product of the retention of the protein in the ER membrane because of the failure of the signal peptidase to cleave the signal sequence from the nascent protein. While this might lead to the appearance of clusterin in the inner nuclear membrane since the ER and nuclear membranes are contiguous, it does not adequately explain the apparent localization of the protein throughout the nucleoplasm.

Clusterin is localized to the nuclei of cells undergoing DNA fragmentation. This may either be because of a generalized breakdown of the nuclei, or because of a specific pathway. As shown by FFE and confocal microscopy after treatment with $\mathrm{TNF} \alpha$ or ICl 182,780 , clusterin accumulates in the ER and nucleus of dying MCF-7 cells. Analysis of multiple fields on confocal microscopy has established that nuclear clusterin accumulation invariably occurs in cells that are TUNEL positive and appears to occur slightly after DNA fragmentation. This suggests that the nuclear accumulation of clusterin occurs via a regulated mechanism, but also makes it unlikely that nuclear clusterin is involved in the activation of the apoptotic endonuclease(s), at least in MCF-7 cells. In a yeast two-hybrid screen clusterin, identified as XIP-8, a radiationinduced protein, ${ }^{59}$ has been shown to bind $\mathrm{Ku} 70$, one of the regulatory components of the DNA-dependent protein kinase responsible for activating double-stranded DNA repair processes. ${ }^{60}$ While these studies utilized a construct of human clusterin that will not produce a disulfide-linked protein (since the signal sequence was removed in the construct and translation consequently initiated on $\alpha^{12} \mathrm{M}$ ), they suggest that the nuclear isoform of clusterin may regulate DNA repair.
Thus, in the context of cell death initiated through the extrinsic pathway by $\mathrm{TNF} \alpha$, or the estrogen receptor-mediated pathway by ICI 182,780 , it is likely that nuclear clusterin leads to the sequestration of Ku70 away from DNA repair processes, leading to the inhibition of DNA repair at a time that endonucleases are responsible for the orderly destruction of the genome. Within this framework, clusterin can be regarded as a sentinel protein, whose translocation to the nucleus ensures that appropriate DNA cleavage ensues without unwanted DNA repair that might lead to substantial genomic instability were the cell to survive.

In summary, the data presented in this report demonstrate that alterations in the biogenesis of clusterin are induced during cell death, apparently as a result of changes in glycosylation and proteolytic processing. These alterations lead to changes in the subcellular location and, almost certainly, in the function of the protein. These observations may reconcile many of the differences in the literature regarding the role of clusterin during apoptosis. If the current observations are extended to other cell types undergoing apoptosis, it would suggest that the nuclear isoform clusterin is neither anti- nor proapoptotic, since it regulates DNA repair processes to prevent inappropriate DNA repair and genomic instability. It is interesting to note that these changes in clusterin function, while having profound effects on the cell, do not involve mutations in the gene, but rather represent an example of the major epigenetic effects that are not detectable using genetic methodologies such as positional cloning or genomic analysis.

\section{Materials and Methods}

\section{Determination of cell growth}

MCF-7, an estrogen receptor-positive and hormone-sensitive human breast carcinoma cell line was obtained from ATCC and maintained as a monolayer culture in $\alpha$-MEM with Earle's salts, L-glutamine with HEPES, $\mathrm{NaHCO}_{3}$, glucose, supplemented with $5 \%$ fetal bovine serum (FBS) and streptomycin sulfate/penicillin. Crystal violet assays were used to measure cell growth. MCF-7 cells were plated at $2 \times 10^{4}$ cells per well in 24-well dishes, grown overnight in serum containing $\alpha$-MEM medium and transferred to phenol red-free medium supplemented with $5 \%$ charcoalstripped serum (CSS) and $10 \mathrm{nM} 17 \beta$-estradiol prior to treatment. At various times after treatment, the cells were fixed in $1 \%$ glutaraldehyde for $15 \mathrm{~min}$ at room temperature. Crystal violet solution $(0.1 \%)$ was added and incubated for $30 \mathrm{~min}$ at room temperature. Excess dye was discarded and $0.2 \%$ Triton X-100 was added to each well. Control cultures were treated with PBS, ethanol or methanol, all of which were used as vehicle controls where appropriate. Absorbances were measured at $A_{590}$ using a Victor $^{2}$ microplate reader (Wallac, Gaithersburg, MD, USA).

\section{Statistical evaluation}

Statistical analyses were performed using GraphPad Instat (GraphPad Software, San Diego, CA, USA). Data are expressed as mean \pm S.E.M. One-way analysis of variance was used to assess statistical significance between means. Differences between means were considered significant if $P$-values less than 0.05 were obtained using the Bonferroni method. 


\section{Cell growth conditions for FFE}

FFE is a gentle, fast and efficient method for the preparative separation of cell organelles and membrane systems. ${ }^{61-63}$ MCF-7 cells were seeded at $1 \times 10^{7} / \mathrm{ml}$ in roller bottles, incubated in $\alpha$-MEM supplemented with $5 \%$ FBS and streptomycin sulfate/penicillin for $48 \mathrm{~h}$ prior to treatment and transferred to phenol red-free medium supplemented with $5 \%$ CSS and $10 \mathrm{nM} 17 \beta$-estradiol $24 \mathrm{~h}$ prior to treatment and harvested at fixed times of treatment. For individual experiments, MCF-7 cells were treated with either $1 \mathrm{ng} / \mathrm{ml} \mathrm{TNF} \alpha$, or $10 \mu \mathrm{M} \mathrm{ICl} 182,780$ or $5 \mu \mathrm{g} / \mathrm{ml} \mathrm{BFA}$, prior to harvest at times at which the majority of cells were determined to be in the early stages of the apoptotic process prior to the formation of apoptotic bodies ( $24 \mathrm{~h}$ after treatment for $\mathrm{TNF} \alpha$, or $\mathrm{ICl} 182,780$ treatment and $6 \mathrm{~h}$ for BFA experiments). Control cultures were treated with ethanol or methanol (as vehicle controls).

\section{Cell homogenization using a ball-bearing cell cracker}

All manipulations and solutions were at $0-4^{\circ} \mathrm{C}$ unless otherwise indicated. Monolayers were rinsed twice with cold PBS and trypsinized. The viable cells were resuspended in $\mathrm{TEAs}_{250}(0.25 \mathrm{M}$ sucrose, $10 \mathrm{mM}$ triethanolamine, $10 \mathrm{mM}$ acetic acid, $1 \mathrm{mM}$ EDTA, pH 7.4) at a density of $3 \times 10^{7} / \mathrm{ml}$, placed on ice for $5 \mathrm{~min}$ and homogenized with a ball-bearing cell cracker (custom made by $\mathrm{H} \&$ Y Enterprises, Redwood City, CA, USA). The optimum clearance and the number of passages needed to obtain $80 \%$ cell breakage while leaving greater than $90 \%$ of the nuclei intact were determined empirically using trypan blue dye exclusion assay. For the untreated MCF-7 cells, cells were passed through the homogenizer five times using a clearance of $27.9 \mu \mathrm{m}$, whereas treated MCF-7 cells passed through the homogenizer five times with a clearance of $22.8 \mu \mathrm{m}$. The difference in clearance between untreated and treated cells is attributable to the slight but significant decrease in the diameter of the cells after treatment with $\mathrm{TNF} \alpha, \mathrm{ICl} 182,780$ or BFA (O'Sullivan, unpublished observations). The homogenates were incubated at room temperature for $10 \mathrm{~min}$ and centrifuged for $10 \mathrm{~min}$ at $250 \times \mathrm{g}$ to derive the nuclear fraction and the postnuclear supernatant (PNS).

\section{Nuclear isolation}

The nuclear fraction was washed twice in PBS and resuspended in $1 \mathrm{ml}$ buffer A (10 mM HEPES, $1.5 \mathrm{mM} \mathrm{MgCl}_{2}, 10 \mathrm{mM} \mathrm{KCl}, 0.5 \mathrm{mM}$ DTT, $0.25 \mathrm{mM}$ PMSF, $0.25 \mathrm{mM}$ benzaminide $10 \mu \mathrm{g} / \mathrm{ml}$ leupeptin, $10 \mu \mathrm{g} / \mathrm{ml}$ aprotinin and $1 \% \beta$-mercaptoethanol, $\mathrm{pH} 7.9)$, centrifuged at $10000 \times g$ for $10 \mathrm{~min}$ and resuspended in buffer A plus $1 \%$ NP-40 for $10 \mathrm{~min}$ with frequent vortexing. The integrity of the nuclear membranes was verified by light microscopy. The nuclei were layered onto a sucrose cushion $(15 \mathrm{mM}$ HEPES, $60 \mathrm{mM} \mathrm{KCl}, 15 \mathrm{mM} \mathrm{NaCl}, 0.5 \mathrm{mM}$ EGTA, $2 \mathrm{mM}$ EDTA, $0.876 \mathrm{M}$ sucrose, $\mathrm{pH} 7.9$ ) and pelleted at $10000 \times g$ for $10 \mathrm{~min}$. The nuclear pellet was resuspended in buffer $C(20 \mathrm{mM}$ HEPES, $0.2 \mathrm{mM}$ EDTA, $1.5 \mathrm{mM}$ $\mathrm{MgCl}_{2}, 10 \mathrm{mM} \mathrm{KCl}, 0.5 \mathrm{mM}$ DTT, $25 \%$ glycerol, $0.25 \mathrm{mM} \mathrm{PMSF}, 0.25 \mathrm{mM}$ benzamidine, $10 \mu \mathrm{g} / \mathrm{ml}$ leupeptin, $10 \mu \mathrm{g} / \mathrm{ml}$ aprotinin, $\mathrm{pH}$ 7.9) by gentle mixing, incubated on ice for $30 \mathrm{~min}$ and pelleted at $10000 \times \mathrm{g}$ for $5 \mathrm{~min}$. For high salt extraction of nuclear proteins, pellets were incubated for 20 min on ice in $20 \mathrm{mM}$ HEPES, $0.2 \mathrm{mM}$ EDTA, $1.5 \mathrm{mM} \mathrm{MgCl}_{2}, 0.5 \mathrm{mM}$ DTT, $25 \%$ glycerol, $0.25 \mathrm{mM}$ PMSF, $0.25 \mathrm{mM}$ benzamidine, $10 \mu \mathrm{g} / \mathrm{ml}$ leupeptin, $10 \mu \mathrm{g} / \mathrm{ml}$ aprotinin, $420 \mathrm{mM} \mathrm{NaCl}, \mathrm{pH} 7.9$, centrifuged at $10000 \times \mathrm{g}$ for $3 \mathrm{~min}$ and the resulting supernatants stored at $-80^{\circ} \mathrm{C}$. Protein concentrations were determined using the bicinchoninic acid (BCA) protein assay (Pierce, Rockford, IL,USA).

\section{Free flow electrophoresis (FFE)}

The PNS prepared from the cell cracker was made $1.4 \mathrm{M}$ sucrose by the addition of $1.04 \mathrm{vol} 2.5 \mathrm{M}$ sucrose and overlaid with $1.25,0.25 \mathrm{M}$ sucrose and $T E A s_{250}$. The gradient was centrifuged for $1.5 \mathrm{~h}$ at $35000 \mathrm{rpm}$ in a Beckman SW-41Ti rotor. The organelles were collected as low-density membranes (LDM) at the $0.25 / 1.25$ sucrose interface. FFE was performed using an Octopus FFE instrument (Weber $\mathrm{GmBH}$, Germany) at $6^{\circ} \mathrm{C}$ using a constant current of $120 \mathrm{~mA}$ and a field of $1200 \mathrm{~V}$. The LDM samples were fractionated at $50 \mathrm{ml} / \mathrm{min}$ and collected into a 90 -sample fraction collector. The approximate transit time in the separating chamber was $5 \mathrm{~min}$. Individual runs took $30-60 \mathrm{~min}$ depending on the volume of the initial sample.

\section{Marker enzyme assays}

The localization of individual membrane fractions and the purity of the fractions was determined using established marker enzymes for different organelles: $\beta$-hexosaminidase for lysosomes, mann II for the medial Golgi, alkaline phosphodiesterase for the plasma membrane and glucose-6-phosphatase for the ER, essentially as previously described. ${ }^{63-65}$

\section{Cytosolic protein isolation}

Cells were seeded at $1 \times 10^{6} / \mathrm{ml}$ in T75 flasks, grown overnight in serumcontaining culture media and transferred to phenol red-free media supplemented with $5 \%$ CSS and $10 \mathrm{nM} 17 \beta$-estradiol. At various times after treatment, monolayers were trypsinized and the cell suspension was centrifuged at $2000 \mathrm{rpm}$ for $7 \mathrm{~min}$. The cell pellet was then homogenized in RIPA buffer $(10 \mathrm{mM}$ sodium phosphate, $150 \mathrm{mM}$ $\mathrm{NaCl}, 1 \mathrm{mM}$ EDTA, $1 \mathrm{mM}$ DTT, 1\% Nonidet P-40, 1\% sodium deoxycholate, $0.1 \%$ SDS, $10 \mathrm{mM}$ sodium flouride, $10 \mathrm{mM}$ sodium vanadate, $10 \mu \mathrm{g} / \mathrm{ml}$ leupeptin, $1 \mu \mathrm{g} / \mathrm{ml}$ aprotinin, $2 \mathrm{mM}$ Pefabloc, and $1 \mathrm{mM}$ benzamidine, $\mathrm{pH} 7.5)$ to isolate cytosolic protein. The homogenate was placed on ice for $20 \mathrm{~min}$, sonicated three times for $20 \mathrm{~s}$ on ice, centrifuged at $10000 \times g$ for $15 \mathrm{~min}$ and the supernatants stored at $-20^{\circ} \mathrm{C}$ until use.

\section{Immunofluorescence}

Cells were seeded at $2 \times 10^{4}$ cells $/ \mathrm{ml}$ in slide chambers (Nalgene), grown overnight in serum-containing media and transferred to phenol red-free media supplemented with $5 \% \mathrm{CSS}$ and $10 \mathrm{nM} 17 \beta$-estradiol prior to treatment. At various times after treatment, the monolayers were washed twice for 5 min with PBS and fixed with 3.7\% formaldehyde for $10 \mathrm{~min}$ at room temperature. The cells were permeabilized with $100 \%$ cold methanol at $-20^{\circ} \mathrm{C}$ for $6 \mathrm{~min}$, washed and incubated at room temperature in PBS containing $1 \% \mathrm{BSA}$ for $30 \mathrm{~min}$ and then incubated with the appropriate primary antibody for $1 \mathrm{~h}$ with gentle agitation at room temperature, followed by two 10 min washes with PBS containing $1 \%$ BSA. Slides were incubated with secondary antibody for $1 \mathrm{~h}$ at room temperature, followed by three 10 min washes with PBS containing $1 \%$ BSA, mounted with Poly-aqua and processed for confocal laser scanning microscopy using a Nikon microscope (Nikon, Diaphot 200) equipped with Biorad scanning software.

\section{TUNEL analysis and clusterin colocalization}

Cells were seeded at 8000 cells per chamber in CC2-coated chamber slides (Nalge Nunc International, Naperville, IL, USA) and grown as 
described above. Cells were treated with $1-10 \mu \mathrm{M} \mathrm{ICl} 182,780$ or $1-10 \mathrm{ng} /$ $\mathrm{ml} \mathrm{TNF} \alpha$ for $72 \mathrm{~h}$ in DMEM: Hams F12 plus 5\% charcoal-stripped serum and $10 \mathrm{nM}$ estradiol. Following treatment, the monolayers were washed with PBS, fixed with $3.7 \%$ formaldehyde for $10 \mathrm{~min}$ at room temperature and permeabilized with $0.1 \%$ Triton $\mathrm{X}-100$ for $6 \mathrm{~min}$ at $-20^{\circ} \mathrm{C}$. TUNEL analysis was performed according to the In Situ Cell Death Detection Kit (Roche, Indianapolis, IN, USA) using terminal deoxynucleotidyl transferase and fluorescein-labeled nucleotides. Positive controls for TUNEL included MCF-7 cells treated with $1 \mu \mathrm{g} / \mathrm{ml}$ DNase 1 to induce multiple DNA strand breaks. Slides were washed three times for 5 min with PBS prior to mounting. For colocalization studies with clusterin, after the final wash, the slides were incubated with $1 / 10$ dilution of $6 \mathrm{E} 9$, the $\beta$-chain-specific monoclonal anti-clusterin antibody for $2 \mathrm{~h}$ at room temperature followed by incubation with $1 / 200$ dilution of Cy3-labeled anti-mouse IgG for $1 \mathrm{~h}$ at $37^{\circ} \mathrm{C}$ in a humidity chamber, and washed three times for 5 min with PBS. Slides were mounted with Polyaqua and processed for confocal laser scanning microscopy using a Nikon microscope (Nikon, Diaphot 200) equipped with Biorad MRC 1024 scanning software. Z-series images were acquired using LaserSharp 2000 at a magnification of $\times 60$ by the double label method (FITC $488 \mathrm{~nm}$, Cy3 $568 \mathrm{~nm}$ ). Images were projected using Confocal Assistant 4.0 and merged using Adobe Photoshop 5.0.

\section{Western blot analysis}

SDS polyacrylamide gels (12.5\%) were run at $100 \mathrm{~V}$ for $90 \mathrm{~min}$ under reducing conditions. Gels were electroblotted at $200 \mathrm{~mA}$ for $2 \mathrm{~h}$ to nitrocellulose membranes and blocked for $1 \mathrm{~h}$ with $1 \%$ heat-denatured casein. The membranes were probed with the appropriate primary and secondary antibodies. Immunoreactive bands were visualized by chemiluminescence using the Pierce kit (Pierce, Rockford, IL, USA) and exposed to X-Omat AR film (Eastman Kodak Co, Rochester, NY).

\section{Deglycosylation of $\mathrm{N}$-linked oligosaccharides}

Purified nuclear proteins were denatured in $0.5 \%$ SDS $1 \% \beta$ mercaptoethanol for $10 \mathrm{~min}$ at $100^{\circ} \mathrm{C}$ and incubated overnight at $37^{\circ} \mathrm{C}$ with $0.5 \mathrm{M}$ sodium phosphate buffer and $10 \% \mathrm{NP}-40, \mathrm{pH} 7.5$ and $1000 \mathrm{U}$ of PNGase $F(N E B)$ in a total volume of $30 \mu$ l. Mock controls were treated as above, without addition of PNGase $F$, and either incubated overnight or frozen immediately at $-20^{\circ} \mathrm{C}$. Samples were analyzed by SDS-PAGE and clusterin isoforms were visualized by Western analysis using the monoclonal anticlusterin antibody, 6E9 (1/10), and developed using enhanced super signal chemiluminescence kit (Pierce) and exposed to $X$ Omat AR film (Kodak) at room temperature for $10 \mathrm{~min}$.

\section{Mutagenesis}

Mutagenesis was performed using the Site-directed Mutagenesis Kit using Pfu DNA polymerase (Stratagene, La Jolla, CA, USA). Briefly, complementary primer pairs to the template were designed with the desired sequence to be mutated present in the middle of the primer sequence. To mutate the NLS, PCR of the mutated sequence was performed using the following cycle conditions: forward (5'-AGAAGAAGCCGAGAAGGAGAAAGAGGATGC- $\left.3^{\prime}\right)$ and reverse $\left(5^{\prime}\right.$ GCATCCTCTTTCTCCTTCTCGGCTTCTTCT-3') primers, containing the sequences to be mutated (underlined), were used to PCR amplify the mutated DNA using the following conditions: hot start $30 \mathrm{~s}$ at $95^{\circ} \mathrm{C}, 30 \mathrm{~s}$ at $95^{\circ} \mathrm{C}, 1 \mathrm{~min}$ at $60^{\circ} \mathrm{C}, 9$ min at $68^{\circ} \mathrm{C}$, for 30 cycles. The PCR-amplified DNA was restriction digested with Dpn1 and transformed into XLI-Blu highly competent cells. Transformants were screened and sequenced. The resulting mutated cDNA was subcloned into the pcDNA 6 vector containing a myc tag (Invitrogen), sequenced to confirm location of the mutation and stably transected into MCF-7 cells.

\section{Generation of stable transfectants}

MCF-7 cells were seeded at $5 \times 10^{5} \mathrm{cells} / \mathrm{ml}$ in a T25 flask and grown overnight. At $70 \%$ confluency, cells were transfected with the myc tagged mutated clusterin constructs or the empty vector using lipofectamine (Gibco BRL) in serum-free media for approximately $18 \mathrm{~h}$. The transfection serum free media were removed and cells were incubated in serumcontaining media for $24 \mathrm{~h}$ and subsequently selected using $10 \mu \mathrm{g} / \mathrm{ml}$ blasticidin for approximately 10 days. Surviving cells were tested for expression by Western blot analysis using an antibody to the myc tag (Invitrogen)

\section{Antibodies and reagents}

Mouse anti-human clusterin antibody (6E9) that recognizes the $\beta$ chain of clusterin was developed in our laboratory. ${ }^{37}$ The antibody specific for manno II was generously provided by Dr. Kelley Moreman (University of Georgia, Athens, GA, USA) and anti-Gal T by Dr. Eric Berger (University of Zurich, Zurich, Switzerland). BFA was purchased from Sigma and stored as stock solutions in methanol. TNF $\alpha$ was purchased from Sigma and ICl 182,780 was provided by Zeneca plc (Macclesfield, UK).

\section{Acknowledgements}

This work was supported by an operating grant from the USAMRC Breast Cancer Research Program (to MT) and by the Coleman Foundation. LW acknowledges the support of the Susan G. Komen Foundation in the form of a Dissertation Award. We thank Drs. JoEllen Welsh, Colm Morrissey, Breandán Kennedy and Louise Flanagan for their helpful advice and comments on the manuscript.

\section{References}

1. Guenette RS, Corbeil HB, Léger JG, Wong P, Mezl V, Mooibroek M and Tenniswood M (1994) Induction of gene expression during involution of the lactating rat mammary gland. J. Mol. Endocrinol. 12: 47-60.

2. Léger JG, Montpeptit ML and Tenniswood MP (1987) Characterization and cloning of androgen-repressed mRNA's from rat ventral prostate. Biochem. Biophys. Res. Commun. 147: 196-203.

3. Rouleau M, Léger JG and Tenniswood M (1990) Ductal heterogeneity of cytokeratins, gene expression, and cell death in the rat ventral prostate. Mol. Endocrinol. 4: 2003-2013.

4. Léger JG, LeGuellec R and Tenniswood MP (1988) Treatment with antiandrogens induces and androgen repressed gene in the rat ventral prostate. Prostate. 13: 131-142.

5. Bettuzzi S, Hiipakka RA, Gilna P and Liao S (1989) Identification of an androgen-repressed mRNA in rat ventral prostate as coding for sulphated glycoprotein 2 by cDNA cloning and sequence analysis. Biochem. J. 257: 293296.

6. Wong P, Pineault JM, Lakins J, Taillefer D, Léger JG, Wang C and Tenniswood M (1993) Genomic organization and expression of TRPM-2 (clusterin) gene, a gene implicated in apoptosis. J. Biol. Chem. 268: 5021-5031.

7. Strange R, Li F, Saurer S, Burkhardt A and Friis RR (1992) Apoptotic cell death and tissue remodelling during mouse mammary gland involution. Development 115: 49-58.

8. Simboli-Campbell M, Narvaez CJ, Tenniswood M and Welsh JE (1996) 1,25 Dihydroxyvitamin D3 induces morphological and biochemical marker of apoptosis in MCF-7 breast cancer cells. J Steroid. Biochem. Mol. Biol. 54: 367-376. 
9. Purrello M, Bettuzzi S, DiPetro C, Mirabile E, Di Blasi M, Rimini R, Grzeschik KH, Ingletti C, Corti A and Sichel G (1991) The gene for SP-40,40, human homolog of rat sulfated glycoprotein 2, rat clusterin, and rat testosterone-repressed prostate message 2, maps to chromosome 8 . Genomics. 10: 151-156.

10. Wong P, Taillefer D, Lakins J, Pineault J, Chader G and Tenniswood M (1994) Molecular characterization of human TRPM2/clusterin, a gene associated with sperm maturation, apoptosis and neurodegeneration. Eur. J. Biochem. 221: 917-925.

11. Birkenmeier EH, Letts VA, Frankel WN, Magenheimer BS and Calvet JP (1993) Sulfated glycoprotein (Sgp-2) maps to mouse chromosome 14. Mamm. Genome 4: 131-132.

12. Jordan-Starck TC, Lund SD, Witte DP, Aronow BJ, Ley CA, Stuart WD, Swertfager DK, Clayton LR, Sells SF, Paigen B and Harmony JA (1994) Mouse apolipoprotein $\mathrm{J}$ : characterization of a gene implicated in atherosclerosis. J. Lipid Res. 35: 194-210.

13. Rowling PJE and Freedman RE (1993) Folding, assembly, and posttranslational modification of proteins within the lumen of the endoplasmic reticulum. Subcell. Biochem. 21: 41-80.

14. Kapron JT, Hilliard GM, Lakins JN, Tenniswood MP, West KA, Carr SA and Crabb JW (1997) Identification and characterization of glycosylation sites in human serum clusterin. Protein Sci. 6: 2120-2133.

15. Choi-Miura NH, Takahashi $Y$, Nakano $Y$, Tobe $T$ and Tomita M (1992) Identification of the disulfide bonds in human plasma protein SP-40,40 (apolipoprotein-J). J. Biochem. 112: 557-561.

16. Wünsche W, Tenniswood MP, Schneider MR and Vollmer G (1998) Estrogenic regulation of clusterin $\mathrm{mRNA}$ in normal and malignant endometrial tissue. Int. J. Cancer 76: 684-688.

17. Buttyan R, Olsson CA, Pintar J, Chang C, Bandyk M, Ng PY and Sawczuk IS (1989) Induction of the TRPM-2 gene in cells undergoing programmed death. Mol. Cell. Biol. 9: 3473-3481.

18. Correa-Rotter R, Ibarra-Rubio ME, Schwochau G, Cruz C, Silkensen JR, Pedraza-Chaverri J, Chielewesk D and Rosenberg ME (1998) Induction of clusterin in tubules of nephrotic rats. J. Am. Soc. Nephrol. 9: 33-37.

19. Calvo EL, Mallo GV, Fiedler F, Malka D, Vaccaro MI, Keim V, Morisset JL, Dagorn JC and lovanna JL (1998) Clusterin overexpression in rat pancreas during the acute phase of pancreatitis and pancreatic development. Eur. J. Biochem. 254: 282-289.

20. Danik M, Chabot JG, Hassan-Gonzalez M, Suh M and Quiron R (1993) Localization of sulfated glycoprotein-2/clusterin mRNA in the rat brain by in situ hybridization. J. Comp. Neurol. 334: 209-227.

21. May PC (1993) Sulfated glycoprotein 2: an emerging molecular marker of neurodegeneration. Ann. NY Acad. Sci. 679: 235-244.

22. Witte DP, Aronow BJ, Dry JK and Harmony JA (1994) Temporally and spatially restricted expression of apolipoprotein $\mathrm{J}$ in the developing heart defines discrete stages of valve morphogenesis. Dev. Dyn. 201: 290-296.

23. Wong P, Borst DE, Farber D, Danciger JS, Tenniswood M, Chader GJ and Van Veen T (1994) Increased TRPM-2/clusterin mRNA levels during the time of retinal degeneration in mouse models of retinitis pigmentosa. Biochem. Cell Biol. 72: 439-446.

24. Collard MW and Griswold MD (1987) Biosynthesis and molecular cloning of sulfated glycoprotein 2 secreted by rat Sertoli cells. Biochemistry 26 : 3297-3303.

25. Clark AM and Griswold MD (1997) Expression of clusterin/sulfated glycoprotein-2 under conditions of heat stress in rat Sertoli cells and a mouse Sertoli cell line. J. Androl. 18: 257-263.

26. Kirszbaum L, Bozas SE and Walker ID (1992) SP-40,40, a protein involved in the control of the complement pathway, possesses a unique array of disulfide bridges. FEBS Lett. 297: 70-76.

27. Aronow BJ, Lund SD, Brown TL, Harmony JA and Witte DP (1993) Apolipoprotein $\mathrm{J}$ expression at fluid-tissue interfaces: potential role in barrier cytoprotection. Proc. Natl. Acad. Sci. USA 90: 725-729.

28. French LE, Wohlwend A, Sappino AP, Tschopp J and Schifferli JA (1994) Human clusterin gene expression is confined to surviving cells during in vitro programmed cell death. J. Clin. Invest. 93: 877-884.

29. Murphy BF, Kirzbaum L, Walker ID and d'Apice AJ (1988) SP-40,40, a newly identified normal human brain serum protein found in the SC5b-9 complex of complement and in the immune deposits in glomerulonephritis. J. Clin. Invest. 81: $1858-1864$
30. Polihronis M, Paizis K, Carter G, Sedal L and Murphy B. (1993) Elevation of human cerebral spinofluid clusterin concentration is associated with acute neuropathology. J. Neurol. Sci. 115: 230-233.

31. Law GL and Griswold MD (1994) Activity and form of sulfated glycoprotein 2 (clusterin) from cultured Sertoli cells, testis, and epididymis of the rat. Biol. Reprod. 50: 669-679.

32. Tschopp J, Jenne DE, Hertig S, Preissner KT, Morgenstern H, Sapino AP and French L (1993) Blood 82: 118-125.

33. Palmer DJ and Christie DL (1990) The primary structure of glycoprotein III from bovine adrenal medullary chromaffin granules. Sequence similarity with human serum SP40,40 and rat Sertoli cell glycoprotein. J. Biol. Chem. 265: 6617-6623.

34. Appel D, Pilarsky C, Graichen R and Koch-Brandt C (1996) Sorting of gp80 (GP III, clusterin), a marker protein for constitutive apical secretion in Madin-Darby canine kidney (MDCK) cell, into the regulated pathway in the pheochromocytoma cell line PC12. Eur. J. Cell Biol. 70: 142-149.

35. Sensibar JA, Sutkowski DM, Raffo A, Buttyan R, Griswold MD, Sylvester SR, Kozlowski JM and Lee C (1995) Prevention of cell death induced by tumor necrosis factor alpha in LNCaP cells by overexpression of sulfated glycoprotein-2 (clusterin). Cancer Res. 55: 2431-2437.

36. Humphreys D, Hochgrebe TT, Easetrbrook-Smith SB, Tenniswood MP and Wilson M (1997) Effects of clusterin overexpression on TNF- $\alpha$ and TGF- $\beta$ mediated death of L929 cells. Biochemistry 36: 15233-15243.

37. Lakins J, Bennett SAL, Chen JH, Arnold J, Morrissey C, Wong P, O'Sullivan J and Tenniswood M (1998) Clusterin biogenesis is altered during apoptosis in the regressing rat ventral prostate. J. Biol. Chem. 273: 27887-27895.

38. Wakeling AE, Dukes M and Bowler J (1991) A potent specific pure antiestrogen with clinical potential. Cancer Res. 51: 3867-3873.

39. Moremen K and Touster O (1985) Biosynthesis and modification of Golgi mannosidase II in HeLa cells. J. Biol. Chem. 260: 6654-6662.

40. Fritz IB, Burdzy K, Setchell B and Blaschuk O (1983) Ram rete testis fluid contains a protein (clusterin) which influences cell-cell interactions in vitro. Biol. Reprod. 28: 1173-1188.

41. Griswold MD, Roberts K and Bishop P (1986) Purification and characterization of a sulfated glycoprotein secreted by Sertoli cells. Biochemistry 25: 72657270 .

42. Sensibar JA, Qian Y, Griswold MD, Sylvester SR, Bardin CW, Cheng CY and Lee C (1993) Localization and molecular heterogeneity of sulfated glycoprotein-2 (clusterin) among ventral prostate, seminal vesicle, testis and epididymis of rats. Biol. Reprod. 49: 233-242.

43. Pearse MJ, O'Bryan M, Fisicaro N, Rogers L, Murphy B and d'Apice AJ (1992) Differential expression of clusterin in inducible models of apoptosis. Int. Immunol. 4: 1225-1231.

44. Humphreys DT, Carver JA, Easterbrook-Smith SB and Wilson MR (1999) Clusterin has chaperone-like activity similar to that of small heat shock proteins. J. Biol. Chem. 274: 6875-6881.

45. Poon S, Easterbrook-Smith SB, Rybchyn MS, Carver JA and Wilson MR (2000) Clusterin is an ATP independent chaperone with broad substrate specificity that stabilizes stressed proteins in a folding-competent state. Biochemistry 39 : 15953-15960.

46. Tenniswood M, Wang Z, Lakins J, Morrissey C, O'Sullivan J and Tang H (1998) Clusterin in the male reproductive tract. J. Androl. 19: 508-516.

47. Rose JK and Doms RW (1988) Regulation of protein export from the endoplasmic reticulum. Ann. Rev. Cell Biol. 4: 257-288.

48. Burkey BF, deSilva HV and Harmony JA (1991) Intracellular processing of apolipoprotein $\mathrm{J}$ precursor to the mature heterodimer. J. Lipid Res. 32 1039-1048.

49. Nakashima T, Sekiguchi T, Kuraoka A, Fukushima K, Shibata Y, Komiyama S and Nishimoto T (1993) Molecular cloning of a human cDNA encoding a novel protein DAD1, whose defect causes apoptotic cell death in hamster BHK21 cells. Mol. Cell. Biol. 13: 6367-6374.

50. Silberstein S, Collins PG, Kelleher DJ and Gilmore R (1995) The essential OST2 gene encodes the $16 \mathrm{kDa}$ subunit of the yeast oligosaccharyltransferase, a highly conserved protein expressed in diverse eukaryotic organisms. J. Cell Biol. 131: 371-383.

51. Kelleher DJ and Gilmore R (1997) DAD1, the defender against apoptotic cell death, is a subunit of the mammalian oligosaccharyltransferase. Proc. Natl. Acad. Sci. USA 94: 4994-4999. 
52. Hong NA, Flannery M, Hsich SN, Cado D, Pedersen R and Winoto A (2000) Mice lacking Dad1, the defender against apoptotic death-1, express abnormal $\mathrm{N}$-linked glycoproteins and undergo increased embryonic apoptosis. Dev. Biol. 220: 76-84.

53. Fujiwara T, Oda K, Yokota S, Takatsuki A and Ikehara Y (1988) Brefeldin A causes disassembly of the Golgi complex and accumulation of secreted proteins in the endoplasmic reticulum. J. Cell Biol. 109: 61-72.

54. Lippincott-Schwartz J, Yuan LC, Bonifacino JS and Klausner RD (1989) Rapid distribution of Golgi proteins into the ER in cells treated with brefeldin A: evidence of membrane cycling from Golgi to ER. Cell 56: 801-813.

55. Lippincott-Schwartz J, Donaldson JG, Schweizer A, Berger EG, Hauri HP Yuan LC and Klausner RD (1990) Microtubule-dependent retrograde transport of proteins into the ER in the presence of brefeldin A suggests an ER recycling pathway. Cell 60: 821-836.

56. Roth J and Berger EG (1982) Immunocytochemical localisation of galactosyltransferase in HeLa cells: codistribution with thiamine pyrophosphatase in trans-Golgi cisternae. J. Cell Biol. 93: 223-229.

57. Reddy KB, Jin G, Karode MC, Harmony JA and Howe PH (1996). Transforming growth factor $\beta$ (TGF- $\beta$ ) induced nuclear localization of apolipoprotein $\mathrm{J}$ / clusterin in epithelial cells. Biochemistry 35: 6157-6163.

58. Akakura K, Bruchovsky N, Rennie PS, Coldman AJ, Goldenberg L, Tenniswood M and Fox K (1996) Effects of intermittent androgen suppression of the stem cell composition and the expression of TRPM-2 (clusterin) gene in the Shionogi carcinoma. J. Steroid. Biochem. Mol. Biol. 59: 501-511.

59. Yang CR, Yeh S, Leskov K, Odengaard E, Hsu H, Chang C, Kinsella TJ, Chen DJ and Boothman DA (1999) Isolation of Ku70-binding proteins (KUBs). Nucleic Acids Res. 27: 2165-2174.

60. Yang CR, Leskov K, Hosley-Eberlein K, Criswell T, Pink JJ, Kinsella T and Boothman DA (2000) Nuclear clusterin/XIP8, an x-ray induced Ku-70 binding protein signals cell death. Proc. Natl. Acad. Sci. USA 97: 5907-5912.

61. Evans WH and Flint N (1985) Subfractionation of hepatic endosomes in Nycodenz gradients and by free flow electrophoresis. Separation of ligandtransporting and receptor-enriched membranes. Biochem. J. 232: 25-32.

62. Hannig K and Heidrich HG (1990) Free Flow Electrophoresis. Darmstadt: GIT Verlag: pp. 119.

63. Harms E, Kern H and Schneider JA (1980) Human lysosomes can be purified from diploid skin fibroblasts by free-flow electrophoresis. Proc. Natl. Acad. Sci. USA 77: 6139-6143.

64. Pool RRJ, Maurey KM and Storrie BI (1983) Characterization of pinocytic vesicles from $\mathrm{CHO}$ cells: resolution of pinosomes from lysosomes by analytical centrifugation. Cell Biol. Int. Rep. 7: 361-367.

65. Green SA, Zimmer KP, Griffiths G and Mellman I (1987) Kinetics of intracellular transport and sorting of lysosomal membranes and plasma membrane proteins. J. Cell Biol. 105: 1227-1240. 